\title{
Social media and e-commerce: A scientometrics analysis
}

\author{
E. Taiebi Javid ${ }^{\mathrm{a}}$, M. Nazari ${ }^{\mathrm{a}}$ and M. R. Ghaeli ${ }^{\mathrm{a}}$
}

\begin{tabular}{l}
${ }^{a}$ Department of Commerce and Busines \\
\hline C H R O N I C L E \\
\hline Article history: \\
Received: October 20, 2018 \\
Received in revised format: Janu- \\
ary 25, 2019 \\
Accepted: February 1, 2019 \\
Available online: \\
February 2, 2019 \\
\hline Keywords: \\
Social media \\
Social networking \\
E-commerce \\
Electronic commerce \\
Social commerce \\
Social media marketing \\
Scientometric \\
\end{tabular}
\begin{abstract}
A B S T R A C T
The purpose of this research is to investigate the status and the evolution of the scientific studies on the effect of social networks on e-commerce. The study seeks to address the status of a set of scientific productions of researchers in the world indexed in Scopus based on scientometrics indicators. In total, 1926 articles were found and the collected data were analyzed using quantitative and qualitative indicators of scientometrics with bibliometrix $R$ software package. The findings show that researches have grown exponentially since 2009 and the trend has continued at relatively stable rates. Thematic analysis shows that the subject had a significant but not well-developed research field .There is a high rate of cooperation with a rich research network among institutions in United States, European and Asian countries. Studies also show that research interest in this area is prevalent in developed countries. In addition, the lack of funds and complex analytical tools may be due to lack of studies in developing countries, especially in Africa. The study of the global trend of research through scientometrics helps managers and researchers in identifying countries and institutions with the greatest potential for scientific production, which allows them to develop their professions.
\end{abstract}

\section{Introduction}

E-commerce is a transaction in which the purchase and sales of goods and services is carried out by the Internet and leads to the import or export of the products. This means that Internet networks act as intermediaries between consumers and manufacturers. Web stores are operating at the heart of the business, and internet users are also buyers and customers. Electronic commerce can also be called "Internet Business". Since the advent of e-commerce, it has undergone many changes with the advent of advanced hardware and software technologies and has grown significantly in recent years. As a result, the desire to buy and sell electronic and virtual exchanges has increased throughout the world and even in the less developed countries. On the other hand, social networks have started moving quickly to serve companies. Their social networks and their growing influence among different users around the world have made them the tools for advertising and e-commerce.

\footnotetext{
* Corresponding author.

E-mail address: rghaeli@nyit.edu (M. R. Ghaeli) 
In recent years, the boundaries between e-commerce and social networking have become increasingly blurred. Many e-commerce websites support the mechanism of social login where users can sign on the websites using their social network identities such as their Facebook or Twitter accounts. Users can also post their newly purchased products on microblogs with links to the e-commerce product web pages (Zhao et al., 2016). Recent studies demonstrate that $93 \%$ of social media users think that companies should engage social media in their businesses, while $85 \%$ of them believe that companies should interact with customers via social media websites (Michaelidou et al., 2011). The increased popularity of social networking sites, such as LinkedIn, Facebook, and Twitter, has opened opportunities for new business models for electronic commerce, often referred to as social commerce. Social commerce involves using Web 2.0 social media technologies and infrastructure to support online interactions and user contributions to assist in the acquisition of products and services. Social media technologies not only provide a new platform for entrepreneurs to innovate but also raise a variety of new issues for e-commerce researchers that require the development of new theories. This could become one of the most challenging research arenas in the coming decade (Liang \& Turban, 2011). Crowdfunding as a new way of financing in the web 2.0 has increased over the last years, but only little is known how project initiators increase their chances of successful fundraising through on-page and off-page communication activities. media richness in the project presentation and a high frequency of project updates leverage fundraising success (Beier \& Wagner, 2015). Consumer-generated social referrals regarding deals significantly boost sales in social commerce (Kim \& Kim, 2018). All this has led companies to adopt their business strategy. Culnan et al. (2010) state that to gain full business value from social media, firms need to develop implementation strategies based on three elements: mindful adoption, community building, and absorptive capacity. Social commerce in this regard represents a shift in consumer's thinking from inefficient individual consumption to collaborative sharing and shopping (Chen et al., 2014). In general, small and large organizations have entered social networks and are trying to discover its benefits. However, nobody can claim that in the field of e-commerce in social networks only advantages and benefits lies. But as with all dimensions of life, there are disadvantages and virtues of the same, and along with each other.

\section{About Bibliometrix R package}

Science mapping is complex and unwieldly because it is multi-step and frequently requires numerous and diverse software tools. Bibliometrix R package is a tool for quantitative research in scientometrics and bibliometrics. Bibliometrix package provides various routines for importing bibliographic data from Scopus, Clarivate Analytics' Web of Science, PubMed and Cochrane databases, performing bibliometric analysis and building data matrices for co-citation, coupling, scientific collaboration analysis and coword analysis (Aria \& Cuccurullo, 2017).

\section{Annual scientific production}

With the objective of ascertaining the international evolution of the subject, a broad range of study was carried out. A total of 1926 original articles and reviews were published on this subject (based on highest cited).

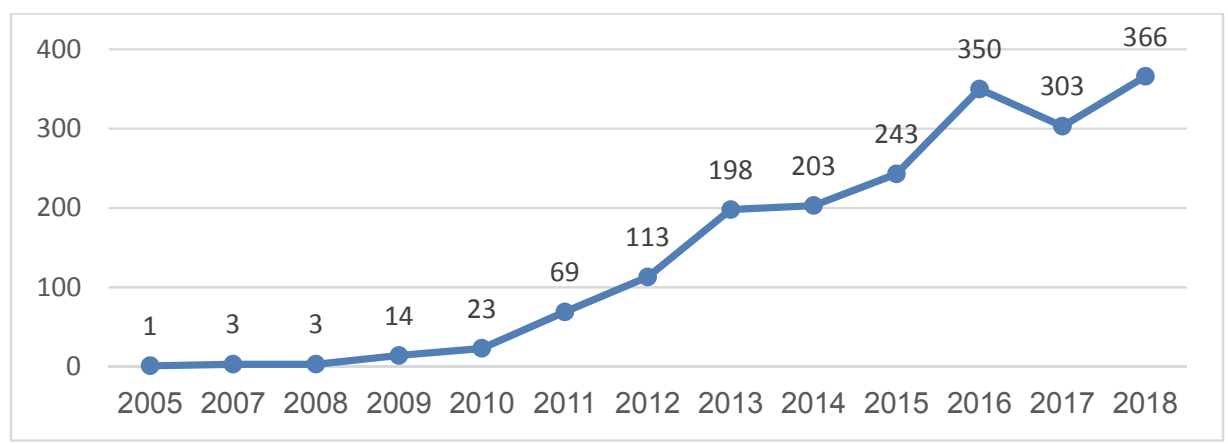

Fig. 1. The Scopus publications on the analysis of social media and e-commerce from 2005 to 2018 
Fig. 1 shows the annual number of articles published in both the social media and e-commerce issues in the Scopus database for a period of 14 years, from 2005 to 2018. Production of articles was stable in the first years of this study (2005-2009). The growing trend in this issue since 2009 shows global attention to the impacts of social media on e-commerce.

\section{The most common keywords and Temporal Analysis}

Table 1 demonstrates some of the most popular keywords used in studies associated with E-commerce. As we can observe from the results of Table 1, "social networking", "Commerce" and "Social media" are three keywords known in the literature. Fig. 1 shows the most important words used over times.

Table 1

The most popular keywords used in studies associated with E-commerce on social media

\begin{tabular}{|c|c|c|c|}
\hline Words & Occurrences & Words & Occurrences \\
\hline social networking (online) & 1016 & female & 36 \\
\hline commerce & 998 & information dissemination & 36 \\
\hline social media & 965 & search engines & 36 \\
\hline marketing & 541 & mobile commerce & 35 \\
\hline electronic commerce & 483 & user-generated content & 35 \\
\hline sales & 223 & word of mouth & 35 \\
\hline data mining & 209 & data handling & 34 \\
\hline information systems & 158 & human computer interaction & 34 \\
\hline sentiment analysis & 150 & communication & 33 \\
\hline social media marketing & 134 & trust & 33 \\
\hline facebook & 126 & classification (of information) & 32 \\
\hline big data & 120 & information use & 32 \\
\hline internet & 119 & online social medias & 32 \\
\hline social commerce & 117 & social sciences computing & 32 \\
\hline world wide web & 109 & strategic planning & 31 \\
\hline economic and social effects & 105 & marketing campaign & 30 \\
\hline consumer behavior & 96 & purchase intention & 30 \\
\hline financial markets & 96 & virtual reality & 30 \\
\hline surveys & 93 & digital storage & 29 \\
\hline forecasting & 90 & information science & 29 \\
\hline websites & 87 & male & 29 \\
\hline decision making & 86 & text mining & 29 \\
\hline human & 82 & social aspects & 28 \\
\hline information management & 82 & social media datum & 28 \\
\hline finance & 81 & students & 28 \\
\hline social media platforms & 79 & algorithms & 27 \\
\hline behavioral research & 75 & design & 27 \\
\hline learning systems & 72 & digital marketing & 27 \\
\hline twitter & 70 & knowledge management & 27 \\
\hline artificial intelligence & 69 & marketing communications & 27 \\
\hline competition & 66 & societies and institutions & 27 \\
\hline investments & 66 & innovation & 26 \\
\hline economics & 60 & competitive advantage & 25 \\
\hline public relations & 57 & planning & 25 \\
\hline purchasing & 53 & research & 25 \\
\hline recommender systems & 51 & social influence & 25 \\
\hline humans & 48 & social interactions & 25 \\
\hline marketing strategy & 48 & content analysis & 24 \\
\hline natural language processing systems & 48 & customer satisfaction & 24 \\
\hline semantics & 46 & ebusiness & 24 \\
\hline industry & 45 & information analysis & 24 \\
\hline commercial phenomena & 44 & motivation & 24 \\
\hline costs & 44 & on-line social networks & 24 \\
\hline web 2.0 & 44 & social network & 24 \\
\hline regression analysis & 43 & distributed computer systems & 23 \\
\hline social networking sites & 43 & information technology & 23 \\
\hline online systems & 40 & learning algorithms & 23 \\
\hline article & 39 & social sciences & 23 \\
\hline education & 39 & united states & 23 \\
\hline social media analytics & 39 & adult & 22 \\
\hline
\end{tabular}




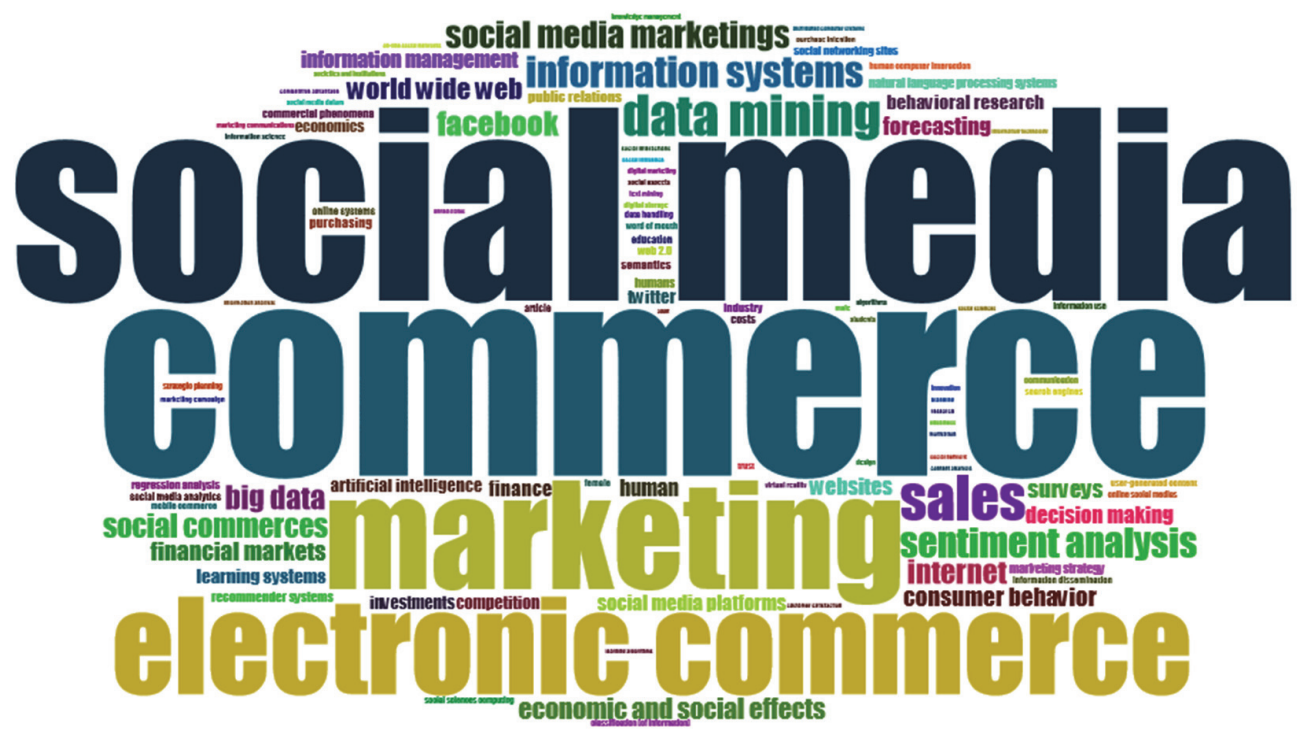

Fig. 2. The frequency of the keywords used in different project

As shown in Fig. 2, "commerce", "social media", "marketing", "electronic commerce", "data mining", "sales", "information systems", "social media marketing" and "sentiment analysis" are the research hotspots with a high frequency of the keywords used in different project. The potential to extract actionable insights from Big Data has gained increased attention of researchers in academia as well as several industrial sectors. The ability to generate value from large volumes of data is an art which combined with analytical skills needs to be mastered in order to gain competitive advantage in business (Arora \& Malik, 2015).

Zhang et al. (2015), in their research on the Dynamic Topic Modeling for Monitoring Market Competition from Online Text and Image Data state: "One of key applications of our work is social media monitoring that can provide companies with temporal summaries of highly overlapped or discriminative topics with their major competitors". There has also been a lot of studies on the analysis of emotions in social media for commercial purposes. For example, tock price prediction using linear regression based on sentiment analysis (Cakra \& Distiawan Trisedya, 2016), deep sentiment analysis for analyzing business ads in social media (Jang et al., 2013) and sentiment analysis of Hollywood movies on Twitter (Hodeghatta, 2013).

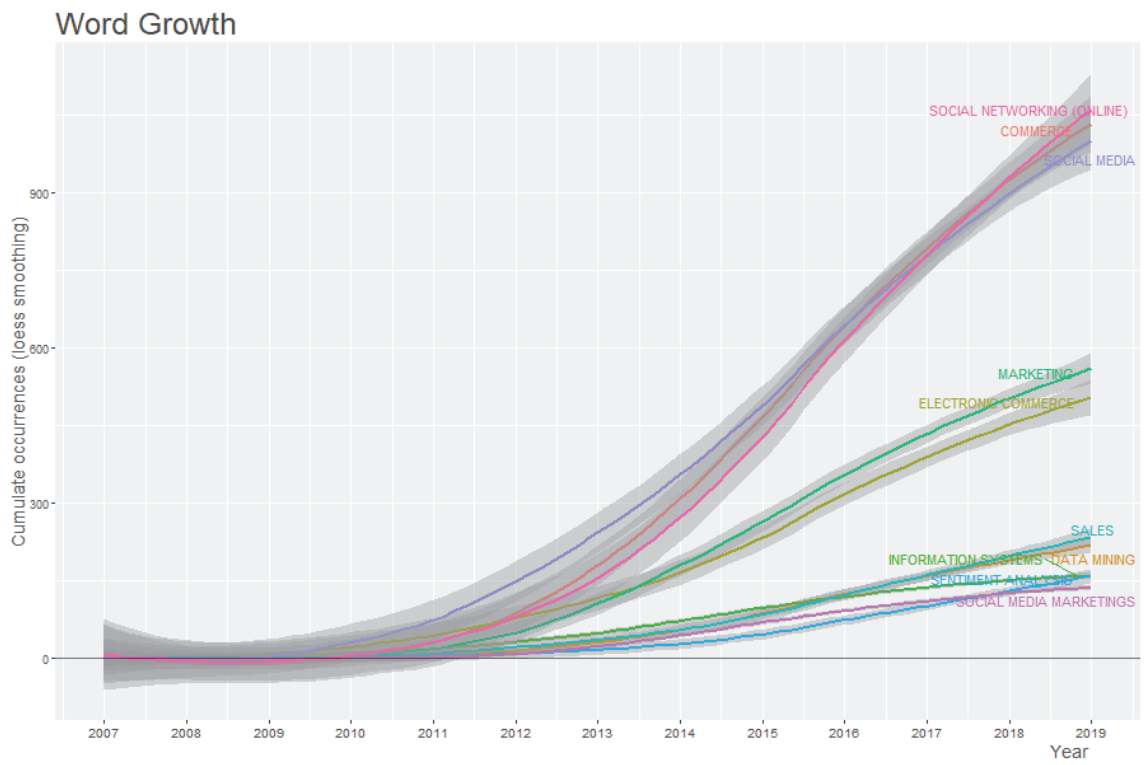

Fig. 3. Word dynamics 
Since 2005, the year the term social commerce was incepted, assumptions and understanding of people in social commerce have moved from a simple and general description of human social nature to a rich exploration with different angles from social psychology, social heuristics, national culture, and economic situations. On the management dimension, business strategies and models have evolved from the short-tail to long-tail thinking, with invented concepts such as branded social networks/communities, niche social networks/communities, niche brands, co-creating, team-buying, and multichannel social networks. Technologically, IT platforms and capabilities for social commerce evolve from blogs, to social networking sites, to media sharing sites, and to smartphones (Wang \& Zhang, 2012). Fig. 3 shows cumulative impact results of temporal keyword growth with confidence interval.

\section{Conceptual structure, Co-occurrence network}

A keywords co-occurrence network $(\mathrm{KCN})$ focuses on understanding the knowledge components and knowledge structure of a scientific/technical field by examining the links between keywords in the literature. Fig. 4 focuses on the analysis methods based on KCNs, which have been used in theoretical and empirical studies to explore research topics and their relationships in selecting scientific fields. If keywords are grouped into the same cluster, they are more likely to reflect identical topics. Each cluster has different number of subject keyword.

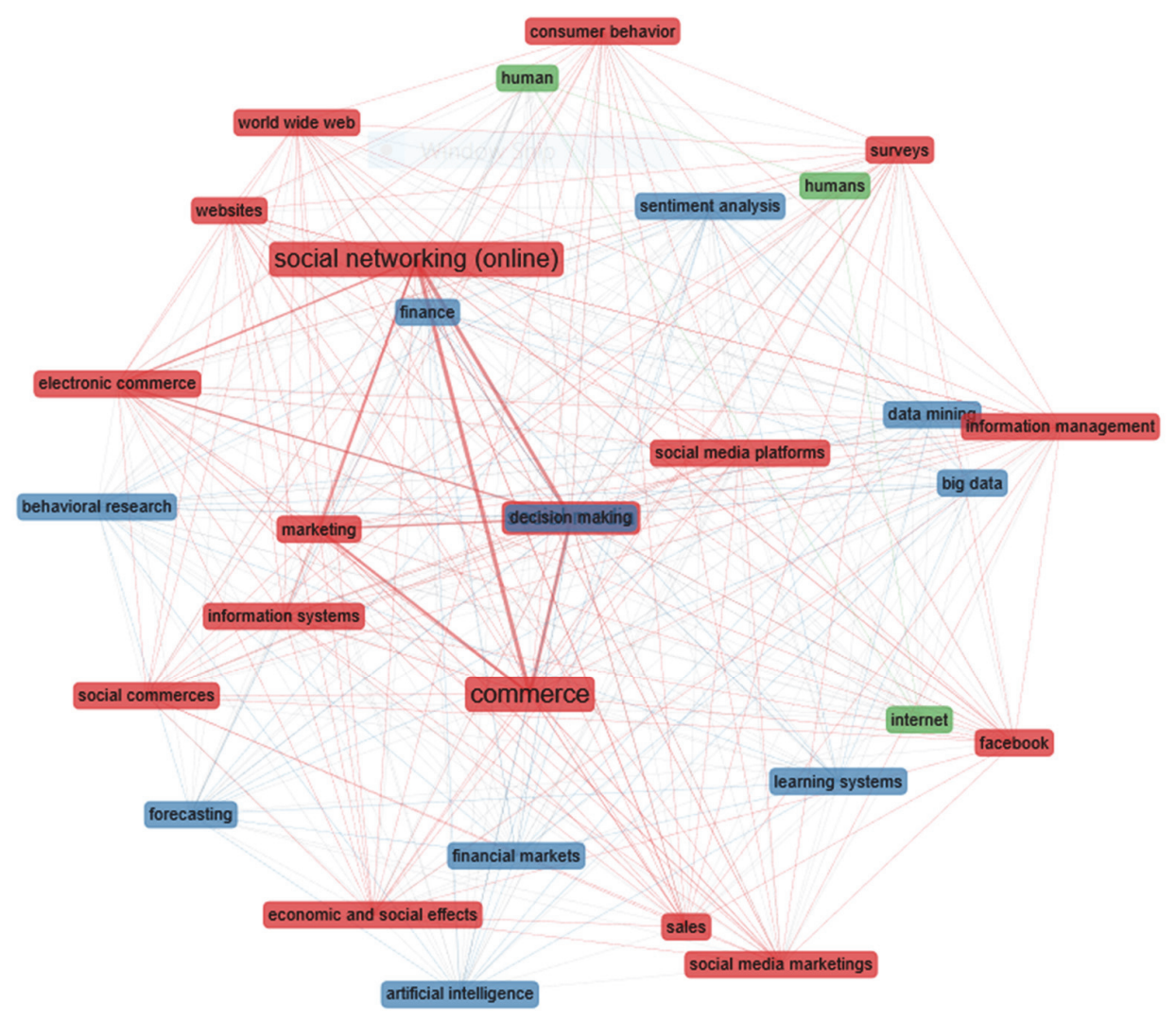

Fig. 4. Co-occurrence network (2005-2018)

To see the growth and evolution of this network more tangibly, Fig. 5 shows the same graph over the period 2005-2009 (beginning of the survey until the first significant growth of articles production). 


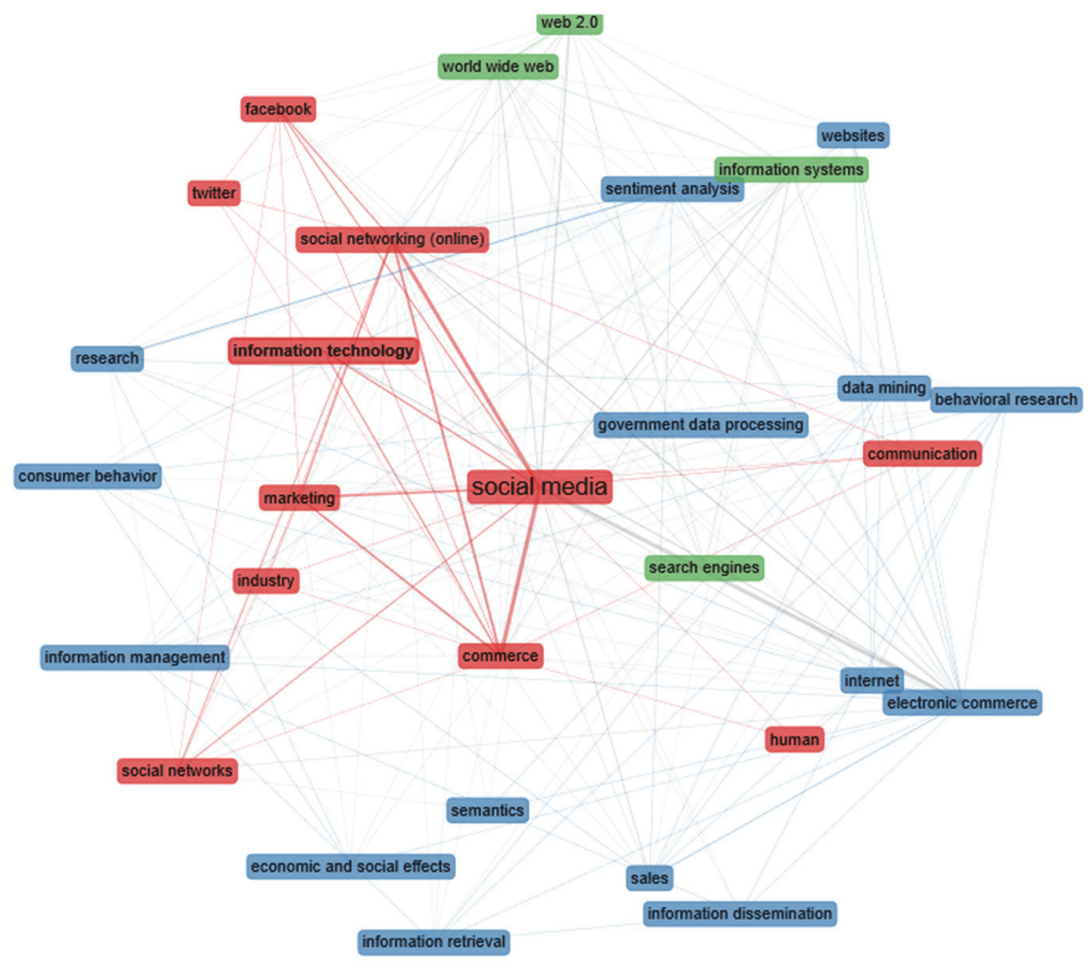

Fig. 5. Co-occurrence network (2005-2009)

\section{Conceptual structure map, Correspondence analysis}

Co-word analysis aims at representing the conceptual structure of a framework using co-occurrence of words. The words can be replaced by authors' keywords, keywords plus, and terms extracted from titles or abstracts. The conceptual structure function produces three kinds of mapping as listed: conceptual structure map, factorial map of the documents with the highest contributes and factorial map of the most cited documents. Conceptual structure map is shown in Fig. 6. Cluster 3 has the most keywords, which means the attention of the researchers to the subject matter of the study.

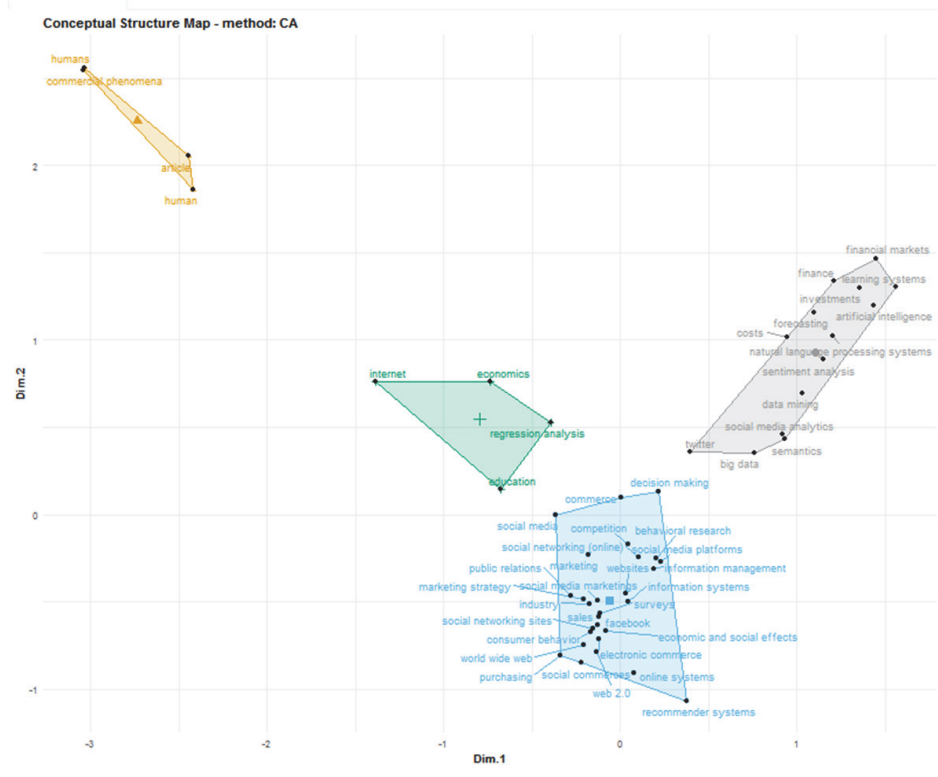

Fig. 6. Conceptual structure Map, method: CA 


\section{Thematic map}

Co-word analysis draws clusters of keywords. They are considered as themes. In the strategic diagram presented in Fig. 7 the vertical axis measures the density - i.e., the strength of the internal links within a cluster represented by a theme -, and the horizontal vertical axis the centrality - i.e. the strength of the links between the theme and other themes in the map.

Thematic map is a very intuitive plot and we can analyze themes according to the quadrant in which they are placed:

(Q1) upper-right quadrant: motor-themes;

(Q2) lower-right quadrant: basic themes;

(Q3) lower-left quadrant: emerging or disappearing themes;

(Q4) upper-left quadrant: very specialized/ niche themes.

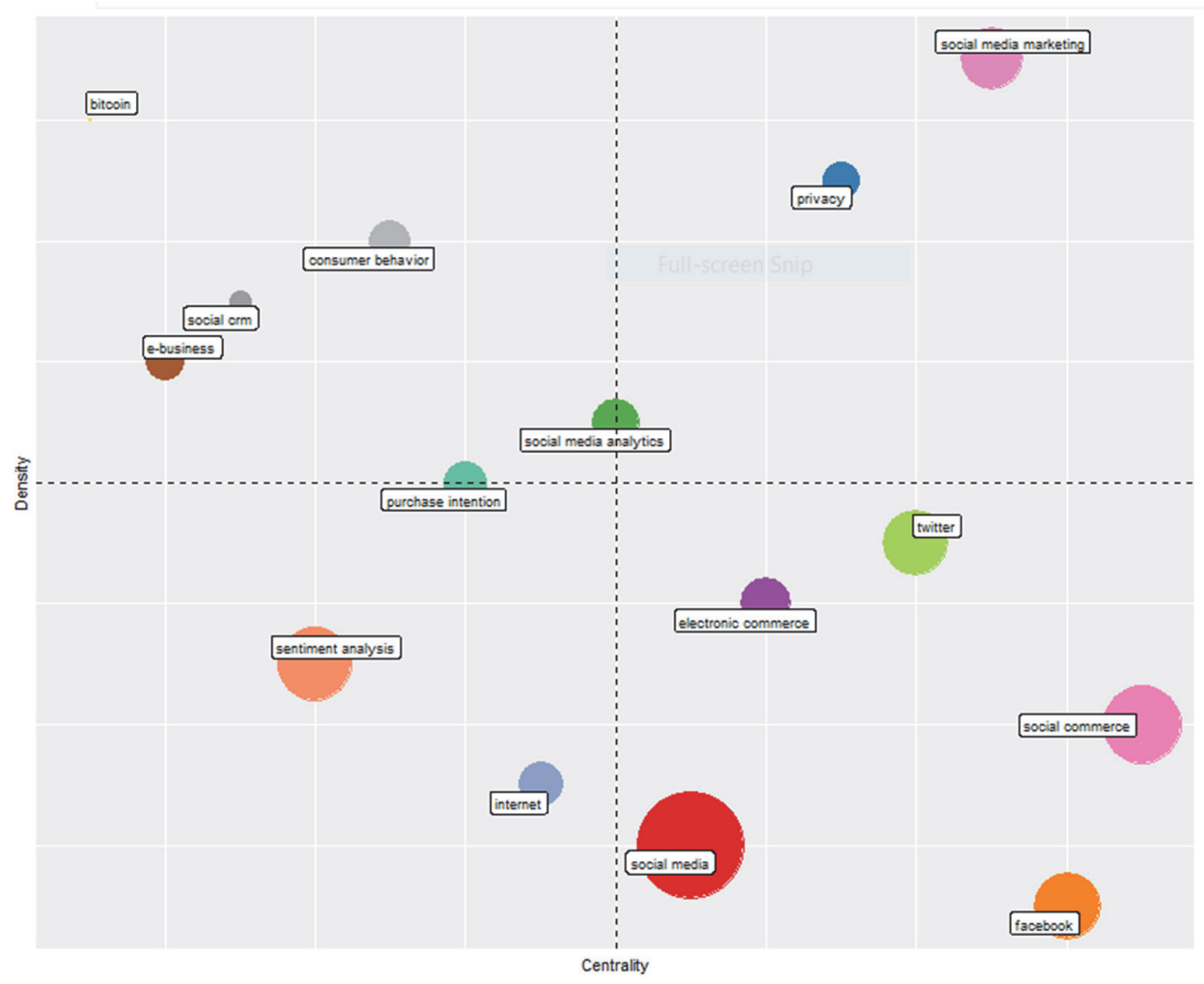

Fig. 7. Thematic Map

Hence, the themes with the highest internal coherence and closest relationship to other themes appear in the first quadrant (the upper right part of the graph). In the second quarter, the following topics can be found: social media, electronic commerce, social commerce, twitter and facebook. Themes in this quadrant are important for a research field but are not developed. This quadrant groups transversal and general, basic themes. 


\section{Intellectual Structure, Historiographic}

The historiographic map is a graph proposed by E. Garfield to represent a chronological network map of the most relevant direct citations resulting from a bibliographic collection. The citation network technique does provide the scholar with a new modus operandi which may significantly affect future historiography.

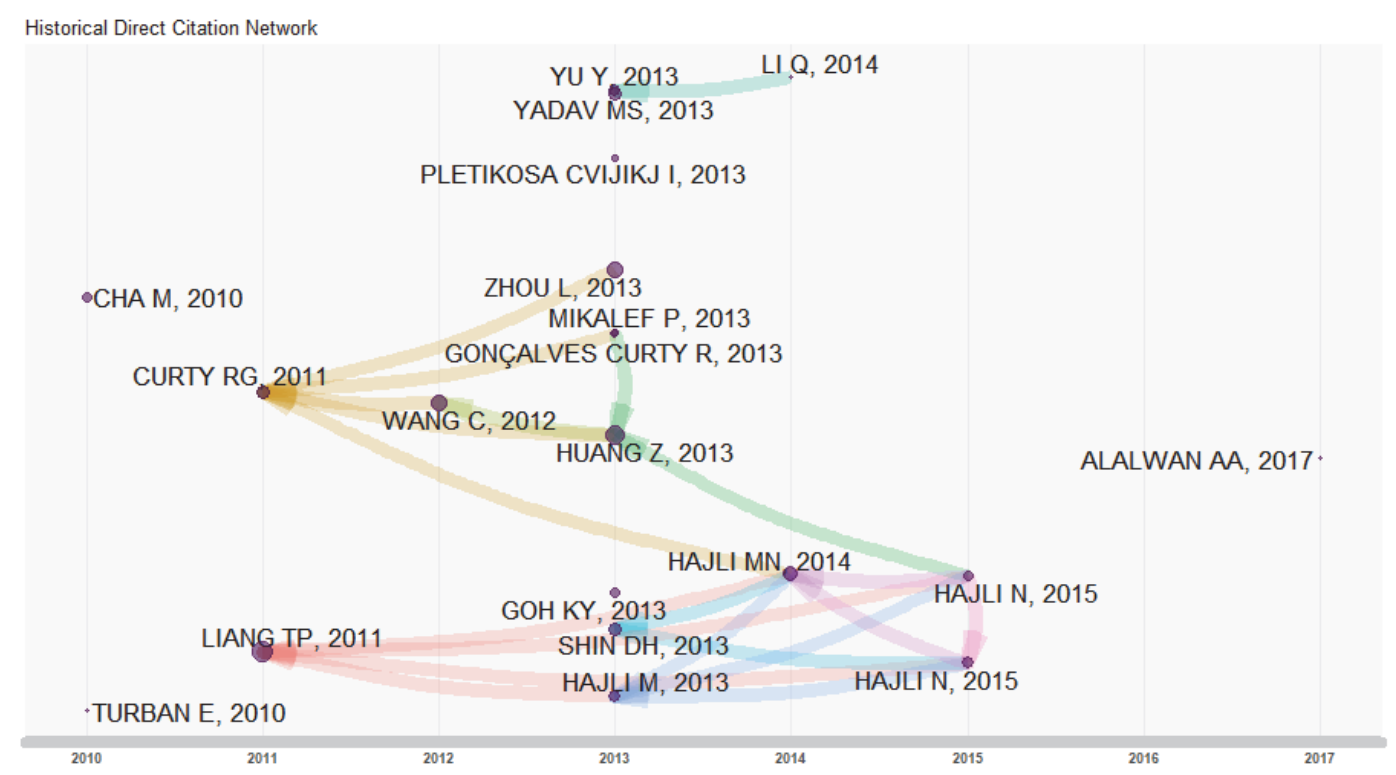

Fig. 8. Historical direct citation network

Fig. 8, shows Curty, (2011), Liang, (2011) and Hajli, (2013) at their own time, were the beginner of new trends. The direction of the arrows in Fig. 8 explains the chronicle change of research trends from the past. Research of Curty (2011) was about qualitative longitudinal study which systematically examined technological features and tools in social commerce websites to illustrate their evolution and impacts on the formation of social commerce practice up to present and its potential future. Liang (2011) aims to provide a framework that will create several elements in social commerce research and summarizes articles in this particular topic. The framework consists of six key elements for classifying social research, the subject of research, social media, business activities, basic theories, results and research methods. The proposed framework has been valuable in determining the scope and identifying of potential research issues in the social commerce and then Hajli, (2013), Goh et al. (2013), Shin, (2013) and Hajli, (2014) provided more development. Hajli, (2013) in his research used social support theory and related theories on intention to use to propose a theoretical framework for the adoption of social commerce. Research of Goh et al. (2013) is about the social media brand community and consumer behavior, and quantifying the relative impact of user-generated and Marketer-Generated Content. Hajli, (2014) studied the role of social support on the quality of communication and social commerce.

\section{Social structure, Contributions of countries}

Our survey demonstrates that the United States with 3060 citations, has took about $30 \%$ of the total citation for e-commerce research on social media in the world and it was ranked first. After that, papers published by researchers in Germany have received the second highest citations (1762), followed by China (748) and Singapore with 487 citations. Table 2 shows details of our survey and according to this table, Germany with the average article citations of 36.708 is ranked first. Although Switzerland has ranked $2^{\text {nd }}$ in total citations, its average article citations is 25.8. Singapore and Canada are ranked third and fourth respectively with 19.48 and 19.36 average article citations, respectively followed by the United States. 
Table 2

The summary of the contributions of different countries

\begin{tabular}{|c|c|c|c|c|c|}
\hline Country & Total Citations & $\begin{array}{l}\text { Average Article Ci- } \\
\text { tations }\end{array}$ & Country & Total Citations & Average Article Citations \\
\hline USA & 3060 & 13.909 & UZBEKISTAN & 37 & 37 \\
\hline GERMANY & 1762 & 36.708 & NEW ZEALAND & 36 & 5.143 \\
\hline CHINA & 748 & 7.262 & OMAN & 34 & 11.333 \\
\hline SINGAPORE & 487 & 19.48 & SWEDEN & 34 & 6.8 \\
\hline CANADA & 484 & 19.36 & INDONESIA & 29 & 0.763 \\
\hline UNITED KINGDOM & 345 & 5.847 & NETHERLANDS & 27 & 2.455 \\
\hline FRANCE & 337 & 17.737 & CZECH REPUBLIC & 23 & 3.286 \\
\hline KOREA & 298 & 7.268 & NORWAY & 21 & 2.625 \\
\hline SWITZERLAND & 258 & 25.8 & POLAND & 18 & 2.571 \\
\hline HONG KONG & 239 & 6.829 & TURKEY & 16 & 2 \\
\hline ITALY & 228 & 7.6 & QATAR & 14 & 2.8 \\
\hline INDIA & 194 & 1.717 & THAILAND & 14 & 1.556 \\
\hline MALAYSIA & 194 & 5.543 & CHILE & 11 & 3.667 \\
\hline TAIWAN & 179 & 4.475 & SLOVAKIA & 10 & 1.25 \\
\hline FINLAND & 153 & 10.929 & AUSTRIA & 8 & 0.8 \\
\hline AUSTRALIA & 144 & 3.892 & SOUTH AFRICA & 8 & 0.8 \\
\hline GREECE & 116 & 5.524 & PAKISTAN & 7 & 2.333 \\
\hline PORTUGAL & 98 & 8.909 & TUNISIA & 7 & 7 \\
\hline JAPAN & 77 & 4.529 & ICELAND & 5 & 2.5 \\
\hline BRAZIL & 74 & 6.167 & KUWAIT & 4 & 1.333 \\
\hline DENMARK & 73 & 14.6 & MAURITIUS & 4 & 2 \\
\hline ISRAEL & 59 & 14.75 & IRAQ & 3 & 3 \\
\hline SPAIN & 57 & 2.478 & MOROCCO & 3 & 0.75 \\
\hline JORDAN & 55 & 6.875 & PERU & 3 & 1.5 \\
\hline MEXICO & 48 & 6.857 & SERBIA & 3 & 1.5 \\
\hline
\end{tabular}

Country Collaboration Map

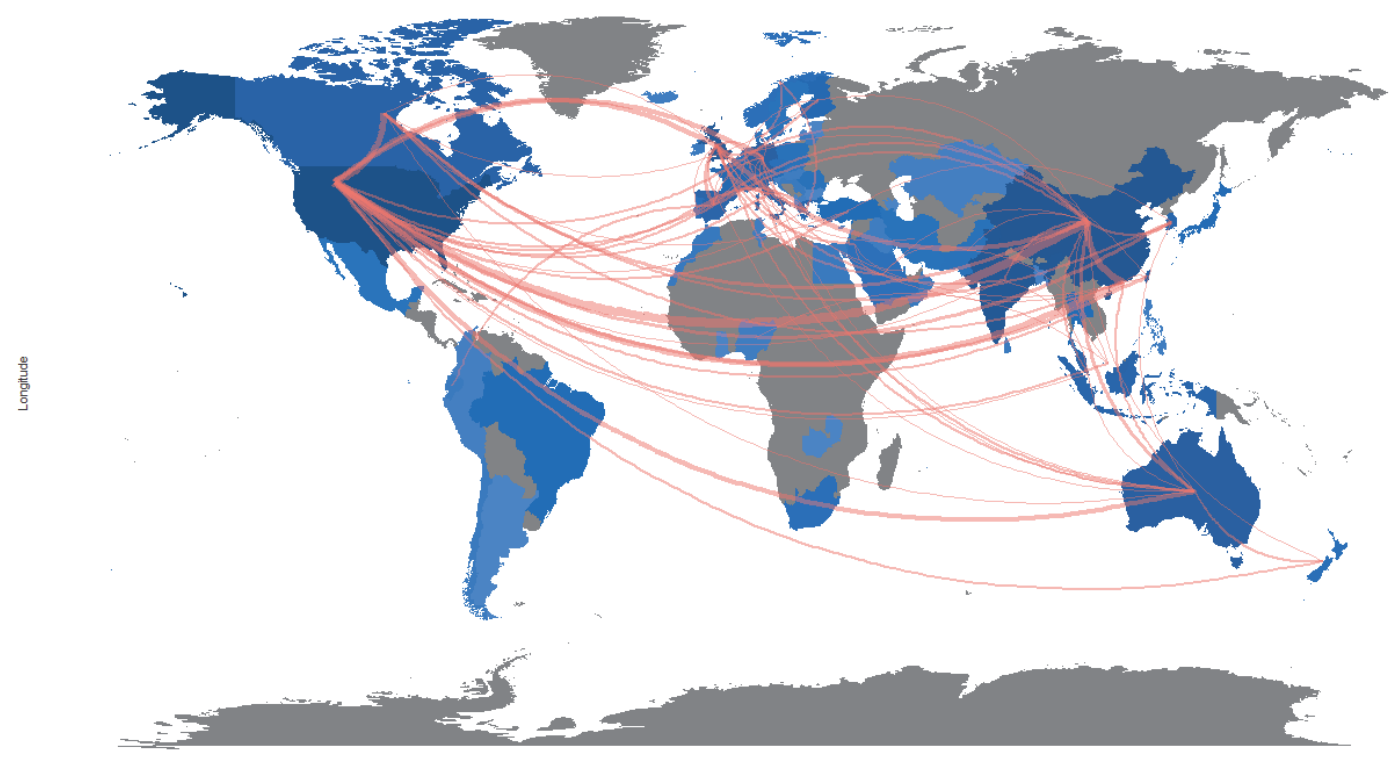

Fig. 9. Country collaboration map

As Fig. 9 shows, the international cooperation of countries in the field of research is highly concentrated. For example, the largest link between the United States and China is described in the graph. The cooperation between China and Hong Kong, the United States with Canada, and the United States and Hong Kong are at the forefront. Also, overall overview of the map shows that in Africa only Nigeria and in the 
South America only Ecuador collaborated with other countries and that other countries are in the lowest rankings. The network between the EU countries is very dense. Integration makes the United States act more than the EU member states. However, China is currently the first United States partner in terms of international cooperation.

\section{Highly cited papers}

The citations function generates the frequency table of the most cited references or the most cited first authors (of references) (Aria \& Cuccurullo, 2017). Although usually articles' citation is considered as an indicator of the impact of papers, the impact of the article cannot be evaluated solely by considering the first influential articles. Newer articles that are truly influential have not yet been seen by more people and, therefore, they have not shown their influence.

Table 3 shows the summary of the most cited articles. As we can observe from the results of Table 3, the study by Cha et al. (2010) has received the highest citations. This paper analyzed the influence of Twitter users by employing three measures that capture different perspectives: indegree, retweets, and mentions. Indegree is the number of people who follow a user; retweets mean the number of times others "forward" a user's tweet; and mentions mean the number of times others mention a user's name. Authors believed that findings of this paper provide new insights for "Viral Marketing".

The second highly cited work belongs to Boyd (2014) where he tried to show the impacts of social media on the quality of teens' lives. The book's conclusions are essential reading not only for parents, teachers, and others who work with teens but also for anyone interested in the impact of emerging technologies on society, culture and commerce.

The third highly cited work is associated with Ghose and Ipeirotis (2011) where they reexamined the impact of reviews on economic outcomes like product sale. They focused on the differences between subjective and objective information and found that an increase in the average subjectivity of product reviews in social media is associated with an increase in sales. Further, a decrease in the deviation of the probability of subjective comments is associated with an increase in product sales. This means that reviews that have a mixture of objective, and highly subjective sentences are negatively associated with product sales, compared to reviews that tend to include only subjective or only objective information.

\section{Table 3}

The summary of the most cited articles

\begin{tabular}{|c|c|c|}
\hline Paper & Total Citations & TC per Year \\
\hline CHA M, 2010, ICWSM - PROC INT AAAI CONF WEBLOGS SOC MEDIA & 1521 & 169 \\
\hline BOYD D, 2014, IT'S COMPLICATED: THE SOC LIVES OF NETWORKED TEENS & 735 & 147 \\
\hline GHOSE A, 2011, IEEE TRANS KNOWL DATA ENG & 435 & 54.375 \\
\hline HUANG Z, 2013, ELECT COMMER RES APPL & 363 & 60.5 \\
\hline CULNAN MJ, 2010, MIS Q EXEC & 352 & 39.1111 \\
\hline GOH KY, 2013, INF SYST RES & 347 & 57.8333 \\
\hline LIANG TP, 2011, INT J ELECT COMMER & 237 & 29.625 \\
\hline RAHIMI MR, 2014, MOBILE NETWORKS APPL & 184 & 36.8 \\
\hline WANG C, 2012, COMMUN ASSOC INFO SYST & 173 & 24.7143 \\
\hline PLETIKOSA CVIJIKJ I, 2013, SOC NETW ANALYSIS MIN & 151 & 25.1667 \\
\hline YU Y, 2013, DECIS SUPPORT SYST & 146 & 24.3333 \\
\hline KHADJEH NASSIRTOUSSI A, 2014, EXPERT SYS APPL & 134 & 26.8 \\
\hline ZHOU L, 2013, ELECT COMMER RES APPL & 129 & 21.5 \\
\hline GHOSE A, 2013, INF SYST RES & 128 & 21.3333 \\
\hline YADAV MS, 2013, J INTERACT MARK & 126 & 21 \\
\hline KAPLAN AM, 2009, BUS HORIZ & 116 & 11.6 \\
\hline ZHANG H, 2014, INF MANAGE & 114 & 22.8 \\
\hline SHIN DH, 2013, BEHAV INF TECHNOL & 106 & 17.6667 \\
\hline HAJLI MN, 2014, TECHNOL FORECAST SOC CHANGE & 103 & 20.6 \\
\hline HAJLI N, 2015, INT J INF MANAGE & 99 & 24.75 \\
\hline HUANG J, 2014, TOB CONTROL & 98 & 19.6 \\
\hline PÖYRY E, 2013, ELECT COMMER RES APPL & 92 & 15.3333 \\
\hline PIOTROWICZ W, 2014, INT J ELECT COMMER & 91 & 18.2 \\
\hline AMARO S, 2015, TOUR MANAGE & 89 & 22.25 \\
\hline BIAN J, 2012, INT CONF INF KNOWLEDGE MANAGE & 87 & 12.4286 \\
\hline
\end{tabular}




\begin{tabular}{|c|c|c|}
\hline ROSARIO AB, 2016, J MARK RES & 86 & 28.6667 \\
\hline PAGANI M, 2011, INT J ELECT COMMER & 80 & 10 \\
\hline CURTY RG, 2011, PROC ASIST ANN MEET & 78 & 9.75 \\
\hline PARASURAMAN A, 2015, J SERV RES & 73 & 18.25 \\
\hline BARDACH NS, 2013, BMJ QUAL SAF & 72 & 12 \\
\hline LAM W, 2012, PROC VLDB ENDOW & 71 & 10.1429 \\
\hline MILLER AR, 2013, INF SYST RES & 70 & 11.6667 \\
\hline SHEN J, 2012, J ELECTR COMMER RES & 70 & 10 \\
\hline YANG CC, 2012, INT CONF INF KNOWLEDGE MANAGE & 69 & 9.8571 \\
\hline GARCIA D, 2014, J R SOC INTERFACE & 66 & 13.2 \\
\hline HAJLI M, 2013, INF MANAGE COMPUT SECUR & 66 & 11 \\
\hline ZHANG Y, 2013, WWW - PROC INT CONF WORLD WIDE WEB & 65 & 10.8333 \\
\hline CLAUSSEN J, 2013, INF SYST RES & 65 & 10.8333 \\
\hline IKEDA K, 2013, KNOWL BASED SYST & 62 & 10.3333 \\
\hline XIANG Z, 2017, TOUR MANAGE & 60 & 30 \\
\hline HE W, 2015, INF MANAGE & 60 & 15 \\
\hline ZHANG KZK, 2014, INT J INF MANAGE & 60 & 12 \\
\hline LUO X, 2013, J MANAGE INF SYST & 59 & 9.8333 \\
\hline BRAOJOS-GOMEZ J, 2015, INT J INF MANAGE & 58 & 14.5 \\
\hline NGO-YE TL, 2014, DECIS SUPPORT SYST & 58 & 11.6 \\
\hline KLAUS P, 2013, J SERV RES & 58 & 9.6667 \\
\hline TANG Q, 2012, J MANAGE INF SYST & 58 & 8.2857 \\
\hline JANSEN BJ, 2011, J INF SCI & 58 & 7.25 \\
\hline KUPAVSKII A, 2012, ACM INT CONF PROC SER & 57 & 8.1429 \\
\hline LAU RYK, 2014, DECIS SUPPORT SYST & 56 & 11.2 \\
\hline PARK H, 2014, J RETAIL CONSUM SERV & 56 & 11.2 \\
\hline CHEUNG CMK, 2014, DECIS SUPPORT SYST & 55 & 11 \\
\hline MIKALEF P, 2013, J THEOR APPL ELECTRON COMMER RES & 55 & 9.1667 \\
\hline LI YM, 2013, DECIS SUPPORT SYST & 55 & 9.1667 \\
\hline GONÇALVES CURTY R, 2013, ELECT COMMER RES APPL & 53 & 8.8333 \\
\hline OESTREICHER-SINGER G, 2012, MANAGE SCI & 53 & 7.5714 \\
\hline CHANG CW, 2014, COMPUT HUM BEHAV & 51 & 10.2 \\
\hline GOPINATH S, 2013, MANAGE SCI & 51 & 8.5 \\
\hline XU SX, 2013, MIS QUART MANAGE INF SYST & 51 & 8.5 \\
\hline ALALWAN AA, 2017, TELEMATICS INF & 50 & 25 \\
\hline TAVANA M, 2013, EXPERT SYS APPL & 50 & 8.3333 \\
\hline DOU Y, 2013, INF SYST RES & 48 & 8 \\
\hline LI Q, 2014, INF SCI & 46 & 9.2 \\
\hline TENG S, 2014, ONLINE INFO REV & 46 & 9.2 \\
\hline ZHAO WX, 2016, IEEE TRANS KNOWL DATA ENG & 45 & 15 \\
\hline RANCO G, 2015, PLOS ONE & 45 & 11.25 \\
\hline HAJLI N, 2015, TECHNOL FORECAST SOC CHANGE & 43 & 10.75 \\
\hline NADEEM W, 2015, INT J INF MANAGE & 42 & 10.5 \\
\hline LI YM, 2014, INF SCI & 42 & 8.4 \\
\hline GHOSE A, 2014, MANAGE SCI & 42 & 8.4 \\
\hline DUWAIRI RM, 2014, INT CONF INF COMMUN SYST, ICICS & 42 & 8.4 \\
\hline YOON VY, 2013, DECIS SUPPORT SYST & 42 & 7 \\
\hline CHHABRA S, 2011, ACM INT CONF PROC SER & 42 & 5.25 \\
\hline YAN Z, 2015, INF MANAGE & 41 & 10.25 \\
\hline DINH TN, 2014, IEEE ACM TRANS NETWORKING & 41 & 8.2 \\
\hline CAMBRIA E, 2013, BIG DATA COMPUTING & 41 & 6.8333 \\
\hline WEI Y, 2011, J ELECTR COMMER RES & 41 & 5.125 \\
\hline EASLEY D, 2013, PROC ACM CONF ELECTRON COMMER & 39 & 6.5 \\
\hline LUNA-NEVAREZ C, 2012, J DESTIN MARK MANAGE & 39 & 5.5714 \\
\hline BADAWY AM, 2009, J ENG TECHNOL MANAGE JET M & 39 & 3.9 \\
\hline TUAROB S, 2013, PROC ASME DES ENG TECH CONF & 38 & 6.3333 \\
\hline BALAJI MS, 2016, INF MANAGE & 37 & 12.3333 \\
\hline HUANG Z, 2015, TECHNOL FORECAST SOC CHANGE & 37 & 9.25 \\
\hline BRENGMAN M, 2012, MANAGE RES REV & 37 & 5.2857 \\
\hline LEVINA N, 2014, INF SYST RES & 36 & 7.2 \\
\hline NERI F, 2012, PROC IEEE/ACM INT CONF ADV SOC NETWORKS ANAL MIN , ASONAM & 36 & 5.1429 \\
\hline CHEN H, 2010, IEEE INTELL SYST & 36 & 4 \\
\hline SIGALA M, 2017, CURR ISSUES TOUR & 35 & 17.5 \\
\hline XIE K, 2015, J MANAGE INF SYST & 35 & 8.75 \\
\hline CANTADOR I, 2015, RECOMMENDER SYSTEMS HANDB, SECOND EDITION & 35 & 8.75 \\
\hline BILGIHAN A, 2014, INF TECHNOL TOUR & 33 & 6.6 \\
\hline MAO Y, 2012, PROC ACM INT WORKSHOP HOT TOP INTERDISCIP SOC NETWORKS RES, & 33 & 4.7143 \\
\hline CHEN A, 2014, J MANAGE INF SYST & 32 & 6.4 \\
\hline WIRTZ BW, 2013, J ELECTR COMMER RES & 32 & 5.3333 \\
\hline ABIDIN C, 2016, SOCIAL MEDIA SOC & 31 & 10.3333 \\
\hline WRIGHT AJ, 2015, OCEAN COAST MANAGE & 31 & 7.75 \\
\hline GUO L, 2015, PROC ACM SIGMOD INT CONF MANAGE DATA & 31 & 7.75 \\
\hline
\end{tabular}




\begin{tabular}{|c|c|c|}
\hline LIU L, 2016, INT J INF MANAGE & 30 & 10 \\
\hline HEW JJ, 2016, COMPUT HUM BEHAV & 30 & 10 \\
\hline LI Q, 2014, DECIS SUPPORT SYST & 30 & 6 \\
\hline MACKEY TK, 2013, J MED INTERNET RES & 30 & 5 \\
\hline MANDIBERG M, 2012, THE SOC MEDIA READ & 30 & 4.2857 \\
\hline ZHAO Z, 2015, BUS HORIZ & 29 & 7.25 \\
\hline LAI LSL, 2015, J ELECTR COMMER RES & 29 & 7.25 \\
\hline BILGIHAN A, 2016, INT J QUAL SERV SCI & 28 & 9.3333 \\
\hline BERNABÉ-MORENO J, 2015, KNOWL BASED SYST & 28 & 7 \\
\hline ROYLE J, 2014, INT J INF MANAGE & 28 & 5.6 \\
\hline SUL HK, 2014, PROC ANNU HAWAII INT CONF SYST SCI & 28 & 5.6 \\
\hline DAVIS R, 2014, J RETAIL CONSUM SERV & 28 & 5.6 \\
\hline BUSALIM AH, 2016, INT J INF MANAGE & 27 & 9 \\
\hline BENSON V, 2015, INF TECHNOL PEOPLE & 27 & 6.75 \\
\hline FENG H, 2014, NEUROCOMPUTING & 27 & 5.4 \\
\hline DEDE E, 2013, IEEE INT CONF CLOUD COMPUT , CLOUD & 27 & 4.5 \\
\hline CAO CC, 2013, PROC ACM SIGKDD INT CONF KNOWL DISCOV DATA MIN & 27 & 4.5 \\
\hline YAN Q, 2016, ELECT COMMER RES APPL & 26 & 8.6667 \\
\hline DORAN D, 2013, PROC IEEE/ACM INT CONF ADV SOC NETWORKS ANAL MIN, ASONAM & 26 & 4.3333 \\
\hline BOTHOS E, 2010, IEEE INTELL SYST & 26 & 2.8889 \\
\hline HASSAN ZADEH A, 2014, DECIS SUPPORT SYST & 25 & 5 \\
\hline TANBEER SK, 2014, J ORG COMPUT ELECTR COMMER & 25 & 5 \\
\hline YAN SR, 2015, INF SCI & 24 & 6 \\
\hline HE W, 2015, IND MANAGE DATA SYS & 24 & 6 \\
\hline WU YCJ, 2015, COMPUT HUM BEHAV & 23 & 5.75 \\
\hline RIBEIRO MT, 2014, ACM TRANS INTELL SYST TECHNOLOG & 23 & 4.6 \\
\hline REINHOLD O, 2011, BLED ECONF - EFUTURE: CREAT SOLUTIONS INDIVID, ORGAN SOC & 23 & 2.875 \\
\hline TURBAN E, 2010, ACM INT CONF PROC SER & 23 & 2.5556 \\
\hline ASWANI R, 2018, INT J INF MANAGE & 22 & 22 \\
\hline WANG Y, 2017, INT J INF MANAGE & 22 & 11 \\
\hline NEIROTTI P, 2016, INT J INF MANAGE & 22 & 7.3333 \\
\hline ZHANG W, 2016, PHYS A STAT MECH APPL & 22 & 7.3333 \\
\hline NGO-YE TL, 2012, ACM TRANS MANAGE INF SYST & 22 & 3.1429 \\
\hline LIN X, 2017, INT J INF MANAGE & 21 & 10.5 \\
\hline CHEN H, 2015, INF SYST RES & 21 & 5.25 \\
\hline LEE SYT, 2015, ELECT COMMER RES APPL & 21 & 5.25 \\
\hline LU Y, 2014, IEEE COMPUT GRAPHICS APPL & 21 & 4.2 \\
\hline SLAVAKIS K, 2014, IEEE SIGNAL PROCESS MAG & 21 & 4.2 \\
\hline NOH M, 2013, J ELECTR COMMER RES & 21 & 3.5 \\
\hline RUI H, 2011, ACM TRANS MANAGE INF SYST & 21 & 2.625 \\
\hline KUMAR S, 2011, PROC NATL CONF ARTIF INTELL & 21 & 2.625 \\
\hline LAI LSL, 2010, WORLD ACAD SCI ENG TECHNOL & 21 & 2.3333 \\
\hline BAETHGE C, 2016, ELECTRON MARK & 20 & 6.6667 \\
\hline JIN X, 2016, PHYS A STAT MECH APPL & 20 & 6.6667 \\
\hline BANERJEE S, 2014, PROC SCI INF CONF , SAI & 20 & 4 \\
\hline PORSHNEV A, 2013, PROC - IEEE INT CONF DATA MIN WORKSHOPS, ICDMW & 20 & 3.3333 \\
\hline KWAHK KY, 2012, PROC ANNU HAWAII INT CONF SYST SCI & 20 & 2.8571 \\
\hline SCHUCKERT M, 2016, ASIA PAC J TOUR RES & 19 & 6.3333 \\
\hline MAKREHCHI M, 2013, PROC - IEEE/WIC/ACM INT CONF WEB INTELL , WI & 19 & 3.1667 \\
\hline TRENZ M, 2013, ECIS - PROC EUR CONF INF SYST & 19 & 3.1667 \\
\hline QIN L, 2011, J ELECTR COMMER RES & 19 & 2.375 \\
\hline DHAR V, 2010, INF SYST RES & 19 & 2.1111 \\
\hline WU C, 2016, PLOS ONE & 18 & 6 \\
\hline
\end{tabular}

\section{Country scientific production}

One of the other important areas of research is the study of the scientific production of countries. Studies show that researchers from the United States (654 articles), China (368 articles), India (291 articles), and the UK (234) have played a major role in scientific production of social networks and e-commerce. 


\section{Country Scientific Production}

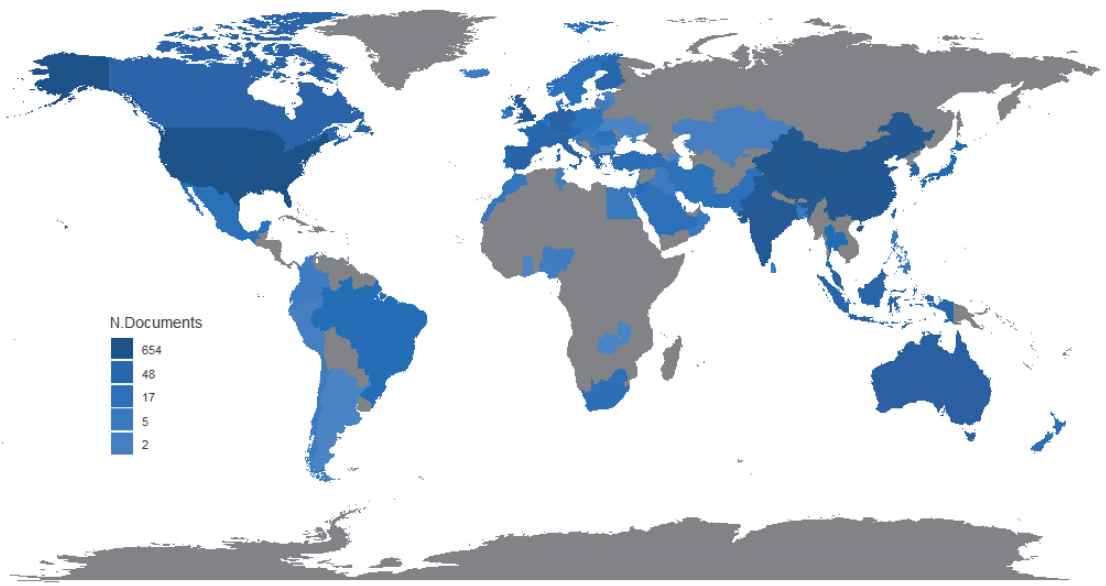

Fig. 10. The frequency of the keywords used in different E-commerce studies

\section{Conclusion}

This study has been in the field of analyzing and illustrating the scientific products of the world for 14 years in the fields of e-commerce and social networks, and has tried to provide a comprehensive review of the research published in the literature. The increasing growth of studies began in 2009 and has continued at an almost constant rate. Thematic analysis shows that the subject under study has a significant but not developed research field and is in a group of transversal and general, basic themes. Studies have shown that researchers in the United States, Germany and China have received the greatest attention in this research. International cooperation in the European Union is well-suited; however, the United States and China have had the highest levels of international cooperation in the field of social networking and e-commerce. Future studies can use existing algorithms to predict the link in the international research network and contribute to research policy developments in the world with the advent of network developments. Also, the study of the relationship between international scientific collaboration and the effectiveness of e-commerce research will determine whether research undertaken through partnerships with other countries has had more citation-effectiveness than its scientific output.

\section{References}

Abed, S. S., Dwivedi, Y. K., \& Williams, M. D. (2015). SMEs' adoption of e-commerce using social media in a Saudi Arabian context: A systematic literature review. International Journal of Business Information Systems, 19(2), 159-179. https://doi.org/10.1504/IJBIS.2015.069429

Abidin, C. (2016a). “Aren't These Just Young, Rich Women Doing Vain Things Online?”: Influencer Selfies as Subversive Frivolity. Social Media and Society, 2(2). https://doi.org/10.1177/2056305116641342

Alalwan, A. A., Rana, N. P., Dwivedi, Y. K., \& Algharabat, R. (2017). Social media in marketing: A review and analysis of the existing literature. Telematics and Informatics, 34(7), 1177-1190. https://doi.org/10.1016/j.tele.2017.05.008

Amaro, S., \& Duarte, P. (2015). An integrative model of consumers' intentions to purchase travel online. Tourism Management, 46, 64-79. https://doi.org/10.1016/j.tourman.2014.06.006

Aria, M., \& Cuccurullo, C. (2017). bibliometrix: An R-tool for comprehensive science mapping analysis. Journal of Informetrics, 11(4), 959-975.

Arora, D., \& Malik, P. (2015). Analytics: Key to go from generating big data to deriving business value. In Proceedings - 2015 IEEE 1st International Conference on Big Data Computing Service and Applications, BigDataService 2015 (pp. 446-452). https://doi.org/10.1109/BigDataService.2015.62

Aswani, R., Kar, A. K., Ilavarasan, P. V., \& Dwivedi, Y. K. (2018). Search engine marketing is not all 
gold: Insights from Twitter and SEOClerks. International Journal of Information Management, 38(1), 107-116. https://doi.org/10.1016/j.ijinfomgt.2017.07.005

Badawy, A. M. (2009). Technology management simply defined: A tweet plus two characters. Journal of Engineering and Technology Management - JET-M, 26(4), 219-224. https://doi.org/10.1016/j.jengtecman.2009.11.001

Baethge, C., Klier, J., \& Klier, M. (2016). Social commerce-state-of-the-art and future research directions. Electronic Markets, 26(3), 269-290. https://doi.org/10.1007/s12525-016-0225-2

Balaji, M. S., Khong, K. W., \& Chong, A. Y. L. (2016). Determinants of negative word-of-mouth communication using social networking sites. Information and Management, 53(4), 528-540. https://doi.org/10.1016/j.im.2015.12.002

Banerjee, S., \& Chua, A. Y. K. (2014). Applauses in hotel reviews: Genuine or deceptive? In Proceedings of 2014 Science and Information Conference, SAI 2014 (pp. 938-942). https://doi.org/10.1109/SAI.2014.6918299

Bardach, N. S., Asteria-Peñaloza, R., John Boscardin, W., \& Adams Dudley, R. (2013). The relationship between commercial website ratings and traditional hospital performance measures in the USA. BMJ Quality and Safety, 22(3), 194-202. https://doi.org/10.1136/bmjqs-2012-001360

Beier, M., \& Wagner, K. (2015). Crowdfunding success: A perspective from social media and ecommerce. In 2015 International Conference on Information Systems: Exploring the Information Frontier, ICIS 2015.

Benson, V., Saridakis, G., \& Tennakoon, H. (2015). Information disclosure of social media users: Does control over personal information, user awareness and security notices matter? Information Technology and People, 28(3), 426-441. https://doi.org/10.1108/ITP-10-2014-0232

Bernabé-Moreno, J., Tejeda-Lorente, A., Porcel, C., Fujita, H., \& Herrera-Viedma, E. (2015). CARESOME: A system to enrich marketing customers acquisition and retention campaigns using social media information. Knowledge-Based Systems, 80, 163-179. https://doi.org/10.1016/j.knosys.2014.12.033

Bian, J., Topaloglu, U., \& Yu, F. (2012). Towards large-scale twitter mining for drug-related adverse events. In International Conference on Information and Knowledge Management, Proceedings (pp. 25-32). https://doi.org/10.1145/2389707.2389713

Bilgihan, A., Kandampully, J., \& Zhang, T. (2016). Towards a unified customer experience in online shopping environments: Antecedents and outcomes. International Journal of Quality and Service Sciences, 8(1), 102-119. https://doi.org/10.1108/IJQSS-07-2015-0054

Bilgihan, A., Okumus, F., Nusair, K., \& Bujisic, M. (2014). Online experiences: Flow theory, measuring online customer experience in e-commerce and managerial implications for the lodging industry. Information Technology and Tourism, 14(1), 49-71. https://doi.org/10.1007/s40558-013-0003-3

Bothos, E., Apostolou, D., \& Mentzas, G. (2010). Using social media to predict future events with agentbased markets. IEEE Intelligent Systems, 25(6), 50-58. https://doi.org/10.1109/MIS.2010.152

Boyd, D. (2014). It's complicated: The social lives of networked teens. It's Complicated: The Social Lives of Networked Teens.

Braojos-Gomez, J., Benitez-Amado, J., \& Javier Llorens-Montes, F. (2015). How do small firms learn to develop a social media competence? International Journal of Information Management, 35(4), 443-458. https://doi.org/10.1016/j.ijinfomgt.2015.04.003

Brengman, M., \& Karimov, F. P. (2012). The effect of web communities on consumers' initial trust in B2C e-commerce websites. Management Research Review, 35(9), 791-817. https://doi.org/10.1108/01409171211256569

Busalim, A. H., \& Hussin, A. R. C. (2016). Understanding social commerce: A systematic literature review and directions for further research. International Journal of Information Management, 36(6), 1075-1088. https://doi.org/10.1016/j.ijinfomgt.2016.06.005

Cakra, Y. E., \& Distiawan Trisedya, B. (2016). Stock price prediction using linear regression based on sentiment analysis. In ICACSIS 2015 - 2015 International Conference on Advanced Computer Science and Information Systems, Proceedings (pp. 147-154). https://doi.org/10.1109/ICACSIS.2015.7415179 
Cambria, E., Rajagopal, D., Olsher, D., \& Das, D. (2013). Big social data analysis. Big Data Computing. https://doi.org/10.1201/b16014

Cantador, I., Fernández-Tobías, I., Berkovsky, S., \& Cremonesi, P. (2015). Cross-domain recommender systems. Recommender Systems Handbook, Second Edition. https://doi.org/10.1007/978-1-48997637-6 27

Cao, C. C., Tong, Y., Chen, L., \& Jagadish, H. V. (2013). Wisemarket: A new paradigm for managing wisdom of online social users. In Proceedings of the ACM SIGKDD International Conference on Knowledge Discovery and Data Mining (Vol. Part F1288, pp. 455-463). https://doi.org/10.1145/2487575.2487642

Cha, M., Haddadi, H., Benevenuto, F., \& Gummadi, K. P. (2010). Measuring user influence in twitter: The million follower fallacy. In ICWSM 2010 - Proceedings of the 4th International AAAI Conference on Weblogs and Social Media (pp. 10-17).

Chang, C.-W., \& Heo, J. (2014). Visiting theories that predict college students' self-disclosure on Facebook. Computers in Human Behavior, 30, 79-86. https://doi.org/10.1016/j.chb.2013.07.059

Chen, A., Lu, Y., Chau, P. Y. K., \& Gupta, S. (2014). Classifying, Measuring, and Predicting Users' Overall Active Behavior on Social Networking Sites. Journal of Management Information Systems, 31(3), 213-253. https://doi.org/10.1080/07421222.2014.995557

Chen, H. (2010). Business and market intelligence 2.0. IEEE Intelligent Systems, 25(1), 68-71. https://doi.org/10.1109/MIS.2010.27

Chen, H., De, P., \& Hu, Y. J. (2015). IT-enabled broadcasting in social media: An empirical study of artists' activities and music sales. Information Systems Research, 26(3), 513-531. https://doi.org/10.1287/isre.2015.0582

Chen, J., Shen, X.-L., \& Chen, Z.-J. (2014). Understanding social commerce intention: A relational view. In Proceedings of the Annual Hawaii International Conference on System Sciences (pp. 1793-1802). https://doi.org/10.1109/HICSS.2014.227

Cheung, C. M. K., Xiao, B. S., \& Liu, I. L. B. (2014). Do actions speak louder than voices? the signaling role of social information cues in influencing consumer purchase decisions. Decision Support Systems, 65(C), 50-58. https://doi.org/10.1016/j.dss.2014.05.002

Chhabra, S., Aggarwal, A., Benevenuto, F., \& Kumaraguru, P. (2011). Phi.sh/\$oCiaL: The phishing landscape through short URLs. In ACM International Conference Proceeding Series (pp. 92-101). https://doi.org/10.1145/2030376.2030387

Claussen, J., Kretschmer, T., \& Mayrhofer, P. (2013). The effects of rewarding user engagement: The case of Facebook apps. Information Systems Research, 24(1), 186-200. https://doi.org/10.1287/isre.1120.0467

Culnan, M. J., McHugh, P. J., \& Zubillaga, J. I. (2010). How large U.S. companies can use twitter and other social media to gain business value. MIS Quarterly Executive, 9(4), 243-259.

Curty, R. G., \& Zhang, P. (2011). Social commerce: Looking back and forward. Proceedings of the ASIST Annual Meeting, 48. https://doi.org/10.1002/meet.2011.14504801096

Davis, R., Piven, I., \& Breazeale, M. (2014). Conceptualizing the brand in social media community: The five sources model. Journal of Retailing and Consumer Services, 21(4), 468-481. https://doi.org/10.1016/j.jretconser.2014.03.006

Dede, E., Sendir, B., Kuzlu, P., Hartog, J., \& Govindaraju, M. (2013). An evaluation of cassandra for hadoop. In IEEE International Conference on Cloud Computing, CLOUD (pp. 494-501). https://doi.org/10.1109/CLOUD.2013.31

Dhar, V., \& Ghose, A. (2010). sponsored search and market efficiency. Information Systems Research, 21(4), 760-772. https://doi.org/10.1287/isre.1100.0315

Dinh, T. N., Zhang, H., Nguyen, D. T., \& Thai, M. T. (2014). Cost-effective viral marketing for timecritical campaigns in large-scale social networks. IEEE/ACM Transactions on Networking, 22(6), 2001-2011. https://doi.org/10.1109/TNET.2013.2290714

Doran, D., Gokhale, S., \& Dagnino, A. (2013). Human sensing for smart cities. In Proceedings of the 2013 IEEE/ACM International Conference on Advances in Social Networks Analysis and Mining, ASONAM 2013 (pp. 1323-1330). https://doi.org/10.1145/2492517.2500240 
Dou, Y., Niculescu, M. F., \& Wu, D. J. (2013). Engineering optimal network effects via social media features and seeding in markets for digital goods and services. Information Systems Research, 24(1), 164-185. https://doi.org/10.1287/isre.1120.0463

Duwairi, R. M., Marji, R., Sha'Ban, N., \& Rushaidat, S. (2014). Sentiment analysis in arabic tweets. In 2014 5th International Conference on Information and Communication Systems, ICICS 2014. https://doi.org/10.1109/IACS.2014.6841964

Easley, D., \& Ghosh, A. (2013). Incentives, gamification, and game theory: An economic approach to badge design. In Proceedings of the ACM Conference on Electronic Commerce (pp. 359-376).

Feng, H., \& Qian, X. (2014). Mining user-contributed photos for personalized product recommendation. Neurocomputing, 129, 409-420. https://doi.org/10.1016/j.neucom.2013.09.018

Garcia, D., Tessone, C. J., Mavrodiev, P., \& Perony, N. (2014). The digital traces of bubbles: Feedback cycles between socio-economic signals in the Bitcoin economy. Journal of the Royal Society Interface, 11(99). https://doi.org/10.1098/rsif.2014.0623

Ghose, A., Goldfarb, A., \& Han, S. P. (2013). How is the mobile internet different? Search costs and local activities. Information Systems Research, 24(3), 613-631. https://doi.org/10.1287/isre.1120.0453

Ghose, A., \& Ipeirotis, P. G. (2011). Estimating the helpfulness and economic impact of product reviews: Mining text and reviewer characteristics. IEEE Transactions on Knowledge and Data Engineering, 23(10), 1498-1512. https://doi.org/10.1109/TKDE.2010.188

Ghose, A., Ipeirotis, P. G., \& Li, B. (2014). Examining the impact of ranking on consumer behavior and search engine revenue. Management Science, 60(7), 1632-1654. https://doi.org/10.1287/mnsc.2013.1828

Goh, K.-Y., Heng, C.-S., \& Lin, Z. (2013). Social media brand community and consumer behavior: Quantifying the relative impact of user- and marketer-generated content. Information Systems Research, 24(1), 88-107. https://doi.org/10.1287/isre.1120.0469

Gonçalves Curty, R., \& Zhang, P. (2013). Website features that gave rise to social commerce: A historical analysis. Electronic Commerce Research and Applications, 12(4), 260-279. https://doi.org/10.1016/j.elerap.2013.04.001

Gopinath, S., Chintagunta, P. K., \& Venkataraman, S. (2013). Blogs, advertising, and local-market movie box office performance. Management Science, 59(12), 2635-2654. https://doi.org/10.1287/mnsc.2013.1732

Guo, L., Zhang, D., Li, G., Tan, K.-L., \& Bao, Z. (2015). Location-aware pub/sub system: When continuous moving queries meet dynamic event streams. In Proceedings of the ACM SIGMOD International Conference on Management of Data (Vol. 2015-May, pp. 843-857). https://doi.org/10.1145/2723372.2746481

Hajli, M. (2013). A research framework for social commerce adoption. Information Management \&amp; Computer Security, 21(3), 144-154. https://doi.org/10.1108/IMCS-04-2012-0024

Hajli, M. N. (2014b). The role of social support on relationship quality and social commerce. Technological Forecasting and Social Change, 87, 17-27. https://doi.org/10.1016/j.techfore.2014.05.012

Hajli, N. (2015). Social commerce constructs and consumer's intention to buy. International Journal of Information Management, 35(2), 183-191. https://doi.org/10.1016/j.ijinfomgt.2014.12.005

Hajli, N., \& Sims, J. (2015). Social commerce: The transfer of power from sellers to buyers. Technological Forecasting and Social Change, 94, 350-358. https://doi.org/10.1016/j.techfore.2015.01.012

Hassan Zadeh, A., \& Sharda, R. (2014). Modeling brand post popularity dynamics in online social networks. Decision Support Systems, 65(C), 59-68. https://doi.org/10.1016/j.dss.2014.05.003

He, W., Shen, J., Tian, X., Li, Y., Akula, V., Yan, G., \& Tao, R. (2015). Gaining competitive intelligence from social media data Evidence from two largest retail chains in the world. Industrial Management and Data Systems, 115(9), 1622-1636. https://doi.org/10.1108/IMDS-03-2015-0098

Hew, J.-J., Lee, V.-H., Ooi, K.-B., \& Lin, B. (2016). Mobile social commerce: The booster for brand loyalty? Computers in Human Behavior, 59, 142-154. https://doi.org/10.1016/j.chb.2016.01.027 
Hodeghatta, U. R. (2013). Sentiment analysis of Hollywood movies on Twitter. In Proceedings of the 2013 IEEE/ACM International Conference on Advances in Social Networks Analysis and Mining, ASONAM 2013 (pp. 1401-1404). https://doi.org/10.1145/2492517.2500290

Huang, J., Kornfield, R., Szczypka, G., \& Emery, S. L. (2014). A cross-sectional examination of marketing of electronic cigarettes on Twitter. Tobacco Control, 23, iii26-iii30. https://doi.org/10.1136/tobaccocontrol-2014-051551

Huang, Z., \& Benyoucef, M. (2013a). From e-commerce to social commerce: A close look at design features. Electronic Commerce Research and Applications, 12(4), 246-259. https://doi.org/10.1016/j.elerap.2012.12.003

Huang, Z., \& Benyoucef, M. (2015). User preferences of social features on social commerce websites: An empirical study. Technological Forecasting and Social Change, 95, 57-72. https://doi.org/10.1016/j.techfore.2014.03.005

Ikeda, K., Hattori, G., Ono, C., Asoh, H., \& Higashino, T. (2013). Twitter user profiling based on text and community mining for market analysis. Knowledge-Based Systems, 51, 35-47. https://doi.org/10.1016/j.knosys.2013.06.020

Jang, H.-J., Sim, J., Lee, Y., \& Kwon, O. (2013). Deep sentiment analysis: Mining the causality between personality-value- attitude for analyzing business ads in social media. Expert Systems with Applications, 40(18), 7492-7503. https://doi.org/10.1016/j.eswa.2013.06.069

Jansen, B. J., Sobel, K., \& Cook, G. (2011). Classifying ecommerce information sharing behaviour by youths on social networking sites. Journal of Information Science, 37(2), 120-136. https://doi.org/10.1177/0165551510396975

Jin, X., Shen, D., \& Zhang, W. (2016). Has microblogging changed stock market behavior? Evidence from China. Physica A: Statistical Mechanics and Its Applications, 452, 151-156. https://doi.org/10.1016/j.physa.2016.02.052

Kaplan, A. M., \& Haenlein, M. (2009). The fairyland of Second Life: Virtual social worlds and how to use them. Business Horizons, 52(6), 563-572. https://doi.org/10.1016/j.bushor.2009.07.002

Khadjeh Nassirtoussi, A., Aghabozorgi, S., Ying Wah, T., \& Ngo, D. C. L. (2014). Text mining for market prediction: A systematic review. Expert Systems with Applications, 41(16), 7653-7670. https://doi.org/10.1016/j.eswa.2014.06.009

Kim, N., \& Kim, W. (2018). Do your social media lead you to make social deal purchases? Consumergenerated social referrals for sales via social commerce. International Journal of Information Management, 39, 38-48. https://doi.org/10.1016/j.ijinfomgt.2017.10.006

Klaus, P. (2013). The case of Amazon.com: Towards a conceptual framework of online customer service experience (OCSE) using the emerging consensus technique (ECT). Journal of Services Marketing, 27(6), 443-457. https://doi.org/10.1108/JSM-02-2012-0030

Kumar, S., Zafarani, R., \& Liu, H. (2011). Understanding user migration patterns in social media. In Proceedings of the National Conference on Artificial Intelligence (Vol. 2, pp. 1204-1209).

Kupavskii, A., Ostroumova, L., Umnov, A., Usachev, S., Serdyukov, P., Gusev, G., \& Kustarev, A. (2012). Prediction of retweet cascade size over time. In ACM International Conference Proceeding Series (pp. 2335-2338). https://doi.org/10.1145/2396761.2398634

Kwahk, K.-Y., \& Ge, X. (2012). The effects of social media on e-commerce: A perspective of social impact theory. In Proceedings of the Annual Hawaii International Conference on System Sciences (pp. 1814-1823). https://doi.org/10.1109/HICSS.2012.564

Lai, L. S.-L. (2010). Social commerce - E-commerce in social media context. World Academy of Science, Engineering and Technology, 72, 39-44.

Lai, L. S. L., \& To, W. M. (2015). Content analysis of social media: A grounded theory approach. Journal of Electronic Commerce Research, 16(2), 138-152.

Lam, W., Liu, L., Prasad, S., Rajaraman, A., Vacheri, Z., \& Doan, A. H. (2012). Muppet: Map reduce style processing of fast data. In Proceedings of the VLDB Endowment (Vol. 5, pp. 1814-1825). https://doi.org/10.14778/2367502.2367520

Lau, R. Y. K., Li, C., \& Liao, S. S. Y. (2014). Social analytics: Learning fuzzy product ontologies for aspect-oriented sentiment analysis. Decision Support Systems, 65(C), 80-94. 
https://doi.org/10.1016/j.dss.2014.05.005

Lee, S.-Y. T., \& Phang, C. W. D. (2015). Leveraging social media for electronic commerce in Asia: Research areas and opportunities. Electronic Commerce Research and Applications, 14(3), 145-149. https://doi.org/10.1016/j.elerap.2015.02.001

Levina, N., \& Arriaga, M. (2014). Distinction and status production on user-generated content platforms: Using Bourdieu's theory of cultural production to understand social dynamics in online fields. Information Systems Research, 25(3), 468-488. https://doi.org/10.1287/isre.2014.0535

Li, Q., Wang, T., Gong, Q., Chen, Y., Lin, Z., \& Song, S.-K. (2014). Media-aware quantitative trading based on public Web information. Decision Support Systems, 61(1), 93-105. https://doi.org/10.1016/j.dss.2014.01.013

Li, Q., Wang, T., Li, P., Liu, L., Gong, Q., \& Chen, Y. (2014). The effect of news and public mood on stock movements. Information Sciences, 278, 826-840. https://doi.org/10.1016/j.ins.2014.03.096

Li, Y.-M., Chou, C.-L., \& Lin, L.-F. (2014). A social recommender mechanism for location-based group commerce. Information Sciences, 274, 125-142. https://doi.org/10.1016/j.ins.2014.02.079

Li, Y.-M., \& Li, T.-Y. (2013). Deriving market intelligence from microblogs. Decision Support Systems, 55(1), 206-217. https://doi.org/10.1016/j.dss.2013.01.023

Liang, T.-P., \& Turban, E. (2011). Introduction to the special issue social commerce: A research framework for social commerce. International Journal of Electronic Commerce, 16(2), 5-13. https://doi.org/10.2753/JEC1086-4415160201

Lin, X., Li, Y., \& Wang, X. (2017). Social commerce research: Definition, research themes and the trends. International Journal of Information Management, 37(3), 190-201. https://doi.org/10.1016/j.ijinfomgt.2016.06.006

Liu, L., Cheung, C. M. K., \& Lee, M. K. O. (2016). An empirical investigation of information sharing behavior on social commerce sites. International Journal of Information Management, 36(5), 686699. https://doi.org/10.1016/j.ijinfomgt.2016.03.013

Lu, Y., Wang, F., \& Maciejewski, R. (2014). Business intelligence from social media: A study from the VAST box office challenge. IEEE Computer Graphics and Applications, 34(5), 58-69. https://doi.org/10.1109/MCG.2014.61

Luna-Nevarez, C., \& Hyman, M. R. (2012). Common practices in destination website design. Journal of Destination Marketing and Management, 1(1-2), 94-106. https://doi.org/10.1016/j.jdmm.2012.08.002

Luo, X., \& Zhang, J. (2013). How do consumer buzz and traffic in social media marketing predict the value of the firm? Journal of Management Information Systems, 30(2), 213-238. https://doi.org/10.2753/MIS0742-1222300208

MacKey, T. K., \& Liang, B. A. (2013). Global reach of direct-to-consumer advertising using social media for illicit online drug sales. Journal of Medical Internet Research, 15(5). https://doi.org/10.2196/jmir.2610

Makrehchi, M., Shah, S., \& Liao, W. (2013). Stock prediction using event-based sentiment analysis. In Proceedings - 2013 IEEE/WIC/ACM International Conference on Web Intelligence, WI 2013 (Vol. 1, pp. 337-342). https://doi.org/10.1109/WI-IAT.2013.48

Mandiberg, M. (2012). The social media reader. The Social Media Reader.

Mao, Y., Wei, W., Wang, B., \& Liu, B. (2012). Correlating S\&amp;P 500 stocks with Twitter data. In Proceedings of the 1st ACM International Workshop on Hot Topics on Interdisciplinary Social Networks Research, HotSocial 2012 (pp. 69-72). https://doi.org/10.1145/2392622.2392634

Mikalef, P., Giannakos, M., \& Pateli, A. (2013). Shopping and word-of-mouth intentions on social media. Journal of Theoretical and Applied Electronic Commerce Research, 8(1), 17-34. https://doi.org/10.4067/S0718-18762013000100003

Miller, A. R., \& Tucker, C. (2013). Active social media management: The case of health care. Information Systems Research, 24(1), 52-70. https://doi.org/10.1287/isre.1120.0466

Michaelidou, N., Siamagka, N. T., \& Christodoulides, G. (2011). Usage, barriers and measurement of social media marketing: An exploratory investigation of small and medium B2B brands. Industrial marketing management, 40(7), 1153-1159. 
Nadeem, W., Andreini, D., Salo, J., \& Laukkanen, T. (2015). Engaging consumers online through websites and social media: A gender study of Italian Generation Y clothing consumers. International Journal of Information Management, 35(4), 432-442. https://doi.org/10.1016/j.ijinfomgt.2015.04.008

Neirotti, P., Raguseo, E., \& Paolucci, E. (2016). Are customers' reviews creating value in the hospitality industry? Exploring the moderating effects of market positioning. International Journal of Information Management, 36(6partA), 1133-1143. https://doi.org/10.1016/j.ijinfomgt.2016.02.010

Neri, F., Aliprandi, C., Capeci, F., Cuadros, M., \& By, T. (2012). Sentiment analysis on social media. In Proceedings of the 2012 IEEE/ACM International Conference on Advances in Social Networks Analysis and Mining, ASONAM 2012 (pp. 919-926). https://doi.org/10.1109/ASONAM.2012.164

Ngo-Ye, T. L., \& Sinha, A. P. (2012). Analyzing online review helpfulness using a Regressional ReliefFenhanced text mining method. ACM Transactions on Management Information Systems, 3(2). https://doi.org/10.1145/2229156.2229158

Ngo-Ye, T. L., \& Sinha, A. P. (2014). The influence of reviewer engagement characteristics on online review helpfulness: A text regression model. Decision Support Systems, 61(1), 47-58. https://doi.org/10.1016/j.dss.2014.01.011

Noh, M., Lee, K., Kim, S., \& Garrison, G. (2013). Effects of collectivism on actual s-commerce use and the moderating effect of price consciousness. Journal of Electronic Commerce Research, 14(3), 244 260.

Oestreicher-Singer, G., \& Sundararajan, A. (2012). The visible hand? Demand effects of recommendation networks in electronic markets. Management Science, 58(11), 1963-1981. https://doi.org/10.1287/mnsc.1120.1536

Pagani, M., \& Mirabello, A. (2011). The influence of personal and social-interactive engagement in social TV web sites. International Journal of Electronic Commerce, 16(2), 41-67. https://doi.org/10.2753/JEC1086-4415160203

Parasuraman, A., \& Colby, C. L. (2015). An Updated and Streamlined Technology Readiness Index: TRI 2.0. Journal of Service Research, 18(1), 59-74. https://doi.org/10.1177/1094670514539730

Park, H., \& Kim, Y.-K. (2014). The role of social network websites in the consumer-brand relationship. Journal of Retailing and Consumer Services, 21(4), 460-467. https://doi.org/10.1016/j.jretconser.2014.03.011

Piotrowicz, W., \& Cuthbertson, R. (2014). Introduction to the special issue information technology in retail: Toward omnichannel retailing. International Journal of Electronic Commerce, 18(4), 5-16. https://doi.org/10.2753/JEC1086-4415180400

Pletikosa Cvijikj, I., Dubach Spiegler, E., \& Michahelles, F. (2013). Evaluation framework for social media brand presence. Social Network Analysis and Mining, 3(4), 1325-1349. https://doi.org/10.1007/s13278-013-0131-y

Pletikosa Cvijikj, I., \& Michahelles, F. (2013). Online engagement factors on Facebook brand pages. Social Network Analysis and Mining, 3(4), 843-861. https://doi.org/10.1007/s13278-013-0098-8

Porshnev, A., Redkin, I., \& Shevchenko, A. (2013). Machine learning in prediction of stock market indicators based on historical data and data from twitter sentiment analysis. In Proceedings - IEEE 13th International Conference on Data Mining Workshops, ICDMW 2013 (pp. 440-444). https://doi.org/10.1109/ICDMW.2013.111

Pöyry, E., Parvinen, P., \& Malmivaara, T. (2013). Can we get from liking to buying? Behavioral differences in hedonic and utilitarian Facebook usage. Electronic Commerce Research and Applications, 12(4), 224-235. https://doi.org/10.1016/j.elerap.2013.01.003

Qin, L. (2011). Word-of-blog for movies: A predictor and an outcome of box office revenue? Journal of Electronic Commerce Research, 12(3), 187-198.

Rahimi, M. R., Ren, J., Liu, C. H., Vasilakos, A. V., \& Venkatasubramanian, N. (2014). Mobile cloud computing: A survey, state of art and future directions. Mobile Networks and Applications, 19(2), 133-143. https://doi.org/10.1007/s11036-013-0477-4

Ranco, G., Aleksovski, D., Caldarelli, G., Grčar, M., \& Mozetič, I. (2015). The effects of twitter sentiment on stock price returns. PLoS ONE, 10(9). https://doi.org/10.1371/journal.pone.0138441

Reinhold, O., \& Alt, R. (2011). Analytical social CRM: Concept and tool support. In 24th Bled 
eConference - eFuture: Creating Solutions for the Individual, Organisations and Society, Proceedings (pp. 226-241).

Ribeiro, M. T., Ziviani, N., De Moura, E. S., Hata, I., Lacerda, A., \& Veloso, A. (2014). Multiobjective Pareto-efficient approaches for recommender systems. ACM Transactions on Intelligent Systems and Technology, 5(4). https://doi.org/10.1145/2629350

Rosario, A. B., Sotgiu, F., De Valck, K., \& Bijmolt, T. H. A. (2016). The effect of electronic word of mouth on sales: A meta-analytic review of platform, product, and metric factors. Journal of Marketing Research, 53(3), 297-318. https://doi.org/10.1509/jmr.14.0380

Royle, J., \& Laing, A. (2014). The digital marketing skills gap: Developing a Digital Marketer Model for the communication industries. International Journal of Information Management, 34(2), 65-73. https://doi.org/10.1016/j.ijinfomgt.2013.11.008

Rui, H., \& Whinston, A. (2011). Designing a social-broadcasting-based business intelligence system. ACM Transactions on Management Information Systems, 2(4). https://doi.org/10.1145/2070710.2070713

Schuckert, M., Liu, X., \& Law, R. (2016). Insights into Suspicious Online Ratings: Direct Evidence from TripAdvisor. Asia Pacific Journal of Tourism Research, 21(3), 259-272. https://doi.org/10.1080/10941665.2015.1029954

Shen, J. (2012). Social comparison, social presence, and enjoyment in the acceptance of social shopping websites. Journal of Electronic Commerce Research, 13(3), 198-212.

Shin, D.-H. (2013). User experience in social commerce: In friends we trust. Behaviour and Information Technology, 32(1), 52-67. https://doi.org/10.1080/0144929X.2012.692167

Sigala, M. (2017). Collaborative commerce in tourism: implications for research and industry. Current Issues in Tourism, 20(4), 346-355. https://doi.org/10.1080/13683500.2014.982522

Slavakis, K., Kim, S.-J., Mateos, G., \& Giannakis, G. B. (2014). Stochastic approximation vis-à-vis online learning for big data analytics. IEEE Signal Processing Magazine, 31(6), 124-129. https://doi.org/10.1109/MSP.2014.2345536

Sood, S. (2012). The death of social media in start-up companies and the rise of s-commerce: Convergence of e-commerce, complexity and social media. Journal of Electronic Commerce in Organizations, 10(2), 1-15. https://doi.org/10.4018/jeco.2012040101

Sul, H. K., Dennis, A. R., \& Yuan, L. (2014). Trading on twitter: The financial information content of emotion in social media. In Proceedings of the Annual Hawaii International Conference on System Sciences (pp. 806-815). https://doi.org/10.1109/HICSS.2014.107

Tanbeer, S. K., Leung, C. K., \& Cameron, J. J. (2014). Interactive Mining of Strong Friends from Social Networks and its Applications in E-Commerce. Journal of Organizational Computing and Electronic Commerce, 24(2-3), 157-173. https://doi.org/10.1080/10919392.2014.896715

Tang, Q., Gu, B., \& Whinston, A. (2012). Content contribution for revenue sharing and reputation in social media: A dynamic structural model. Journal of Management Information Systems, 29(2), 4176. https://doi.org/10.2753/MIS0742-1222290203

Tavana, M., Momeni, E., Rezaeiniya, N., Mirhedayatian, S. M., \& Rezaeiniya, H. (2013). A novel hybrid social media platform selection model using fuzzy ANP and COPRAS-G. Expert Systems with Applications, 40(14), 5694-5702. https://doi.org/10.1016/j.eswa.2013.05.015

Teng, S., Khong, K. W., Goh, W. W., \& Chong, A. Y. L. (2014). Examining the antecedents of persuasive eWOM messages in social media. Online Information Review, 38(6), 746-768. https://doi.org/10.1108/OIR-04-2014-0089

Trenz, M., \& Berger, B. (2013). Analyzing online customer reviews - An interdisciplinary literature review and research agenda. In ECIS 2013 - Proceedings of the 21st European Conference on Information Systems.

Tuarob, S., \& Tucker, C. S. (2013). Fad or here to stay: Predicting product market adoption and longevity using large scale, social media data. In Proceedings of the ASME Design Engineering Technical Conference (Vol. 2 B). https://doi.org/10.1115/DETC2013-12661

Turban, E., Bolloju, N., \& Liang, T.-P. (2010). Social commerce: An e-commerce perspective. In ACM International Conference Proceeding Series (pp. 33-42). https://doi.org/10.1145/2389376.2389382 
Wang, C., \& Zhang, P. (2012). The evolution of social commerce: The people, management, technology, and information dimensions. Communications of the Association for Information Systems, 31(1), 105 127.

Wang, Y., \& Yu, C. (2017). Social interaction-based consumer decision-making model in social commerce: The role of word of mouth and observational learning. International Journal of Information Management, 37(3), 179-189. https://doi.org/10.1016/j.ijinfomgt.2015.11.005

Wei, Y., Straub, D. W., \& Poddar, A. (2011). The power of many: An assessment of managing internet group purchasing. Journal of Electronic Commerce Research, 12(1), 19-43.

Wirtz, B. W., Piehler, R., \& Ullrich, S. (2013). Determinants of social media website attractiveness. Journal of Electronic Commerce Research, 14(1), 11-33.

Wright, A. J., Veríssimo, D., Pilfold, K., Parsons, E. C. M., Ventre, K., Cousins, J., ... McKinley, E. (2015). Competitive outreach in the 21st century: Why we need conservation marketing. Ocean and Coastal Management, 115, 41-48. https://doi.org/10.1016/j.ocecoaman.2015.06.029

Wu, C., Ye, X., Ren, F., Wan, Y., Ning, P., \& Du, Q. (2016). Spatial and social media data analytics of housing prices in Shenzhen, China. PLoS ONE, 11(10). https://doi.org/10.1371/journal.pone.0164553

Wu, Y.-C. J., Shen, J.-P., \& Chang, C.-L. (2015). Electronic service quality of Facebook social commerce and collaborative learning. Computers in Human Behavior, 51, 1395-1402. https://doi.org/10.1016/j.chb.2014.10.001

Xiang, Z., Du, Q., Ma, Y., \& Fan, W. (2017). A comparative analysis of major online review platforms: Implications for social media analytics in hospitality and tourism. Tourism Management, 58, 51-65. https://doi.org/10.1016/j.tourman.2016.10.001

Xie, K., \& Lee, Y.-J. (2015). Social Media and Brand Purchase: Quantifying the Effects of Exposures to Earned and Owned Social Media Activities in a Two-Stage Decision Making Model. Journal of Management Information Systems, 32(2), 204-238. https://doi.org/10.1080/07421222.2015.1063297

Xu, S. X., \& Zhang, X. M. (2013). Impact of wikipedia on market information environment: Evidence on management disclosure and investor reaction. MIS Quarterly: Management Information Systems, 37(4), 1043-1068. https://doi.org/10.25300/MISQ/2013/37.4.03

Yadav, M. S., de Valck, K., Hennig-Thurau, T., Hoffman, D. L., \& Spann, M. (2013). Social commerce: A contingency framework for assessing marketing potential. Journal of Interactive Marketing, 27(4), 311-323. https://doi.org/10.1016/j.intmar.2013.09.001

Yan, Q., Wu, S., Wang, L., Wu, P., Chen, H., \& Wei, G. (2016). E-WOM from e-commerce websites and social media: Which will consumers adopt? Electronic Commerce Research and Applications, 17, 62-73. https://doi.org/10.1016/j.elerap.2016.03.004

Yan, S.-R., Zheng, X.-L., Wang, Y., Song, W. W., \& Zhang, W.-Y. (2015). A graph-based comprehensive reputation model: Exploiting the social context of opinions to enhance trust in social commerce. Information Sciences, 318, 51-72. https://doi.org/10.1016/j.ins.2014.09.036

Yan, Z., Xing, M., Zhang, D., \& Ma, B. (2015). EXPRS: An extended pagerank method for product feature extraction from online consumer reviews. Information and Management, 52(7), 850-858. https://doi.org/10.1016/j.im.2015.02.002

Yang, C. C., Yang, H., Jiang, L., \& Zhang, M. (2012). Social media mining for drug safety signal detection. In International Conference on Information and Knowledge Management, Proceedings (pp. 33-40). https://doi.org/10.1145/2389707.2389714

Yoon, V. Y., Hostler, R. E., Guo, Z., \& Guimaraes, T. (2013). Assessing the moderating effect of consumer product knowledge and online shopping experience on using recommendation agents for customer loyalty. Decision Support Systems, 55(4), 883-893. https://doi.org/10.1016/j.dss.2012.12.024

Yu, Y., Duan, W., \& Cao, Q. (2013). The impact of social and conventional media on firm equity value: A sentiment analysis approach. Decision Support Systems, 55(4), 919-926. https://doi.org/10.1016/j.dss.2012.12.028

Zhang, H., Kim, G., \& Xing, E. P. (2015). Dynamic topic modeling for monitoring market competition from online text and image data. In Proceedings of the ACM SIGKDD International Conference on Knowledge Discovery and Data Mining (Vol. 2015-Augus, pp. 1425-1434). 
https://doi.org/10.1145/2783258.2783293

Zhang, H., Lu, Y., Gupta, S., \& Zhao, L. (2014). What motivates customers to participate in social commerce? the impact of technological environments and virtual customer experiences. Information and Management, 51(8), 1017-1030. https://doi.org/10.1016/j.im.2014.07.005

Zhang, K. Z. K., Cheung, C. M. K., \& Lee, M. K. O. (2014). Examining the moderating effect of inconsistent reviews and its gender differences on consumers' online shopping decision. International Journal of Information Management, 34(2), 89-98. https://doi.org/10.1016/j.ijinfomgt.2013.12.001

Zhang, W., Li, X., Shen, D., \& Teglio, A. (2016). Daily happiness and stock returns: Some international evidence. Physica A: Statistical Mechanics and Its Applications, 460, 201-209. https://doi.org/10.1016/j.physa.2016.05.026

Zhang, Y., \& Pennacchiotti, M. (2013a). Predicting purchase behaviors from social media. In $W W W 2013$ - Proceedings of the 22nd International Conference on World Wide Web (pp. 1521-1531).

Zhao, W. X., Li, S., He, Y., Chang, E. Y., Wen, J.-R., \& Li, X. (2016). Connecting Social Media to ECommerce: Cold-Start Product Recommendation Using Microblogging Information. IEEE Transactions on Knowledge and Data Engineering, 28(5), 1147-1159. https://doi.org/10.1109/TKDE.2015.2508816

Zhao, Z., \& Balagué, C. (2015). Designing branded mobile apps: Fundamentals and recommendations. Business Horizons, 58(3), 305-315. https://doi.org/10.1016/j.bushor.2015.01.004

Zhou, L., Zhang, P., \& Zimmermann, H.-D. (2013). Social commerce research: An integrated view. Electronic Commerce Research and Applications, 12(2), 61-68. https://doi.org/10.1016/j.elerap.2013.02.003

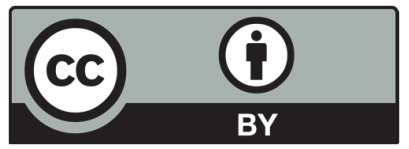

(C) 2019 by the authors; licensee Growing Science, Canada. This is an open access article distributed under the terms and conditions of the Creative Commons Attribution (CC-BY) license (http://creativecommons.org/licenses/by/4.0/). 